\title{
HAZARDOUS TIMES FOR MONETARY POLICY: WHAT DO TWENTY-THREE MILLION BANK LOANS SAY ABOUT THE EFFECTS OF MONETARY POLICY ON CREDIT RISK-TAKING?
}

\author{
By Gabriel Jiménez, Steven Ongena, José-Luis Peydró, \\ AND JESÚS SAURINA ${ }^{1}$
}

\begin{abstract}
We identify the effects of monetary policy on credit risk-taking with an exhaustive credit register of loan applications and contracts. We separate the changes in the composition of the supply of credit from the concurrent changes in the volume of supply and quality, and the volume of demand. We employ a two-stage model that analyzes the granting of loan applications in the first stage and loan outcomes for the applications granted in the second stage, and that controls for both observed and unobserved, time-varying, firm and bank heterogeneity through time $*$ firm and time $*$ bank fixed effects. We find that a lower overnight interest rate induces lowly capitalized banks to grant more loan applications to ex ante risky firms and to commit larger loan volumes with fewer collateral requirements to these firms, yet with a higher ex post likelihood of default. A lower long-term interest rate and other relevant macroeconomic variables have no such effects.
\end{abstract}

${ }^{1}$ For detailed and constructive comments, we thank the editor, four anonymous referees, Philippe Aghion, Manuel Arellano, Sigbjørn Atle Berg, Sudipto Bhattacharya, Lamont Black, José Manuel Campa, Mark Carey, Stephen Cecchetti, Wouter den Haan, Enrica Detragiache, Giovanni Dell'Ariccia, Valeriya Dinger, Gabriele Galati, Paulo Guimaraes, Oliver Hart, Philipp Hartmann, Bengt Holmstrom, Debbie Lucas, Monika Piazzesi, Amit Seru, Andrei Shleifer, Alp Simsek, Frank Smets, Amir Sufi, Jean-Claude Trichet, and participants at the American Finance Association Meetings (San Francisco), the Annual Conference on Bank Structure and Competition on "Credit Market Turmoil: Causes, Consequences, and Cures" (Chicago), CEPR European Summer Symposium in Financial Markets (Gerzensee), the European Central Bank Conference on "The Implications of Changes in Banking and Financing on the Monetary Policy Transmission Mechanism" (Frankfurt), the International Financial Research Forum on "Financial Risks" (Paris), the International Monetary Fund Conference on "Financial Cycles, Liquidity and Securitization" (Washington D.C.), the Financial Intermediation Research Society Conference (Anchorage), the Unicredit Group Banking and Finance Conference on the "Span and Scope of Banks, Stability and Regulation" (Naples), the Annual Research Conference of De Nederlandsche Bank on "Financial Stability and Financial Crises" (Amsterdam), and the Workshop on "Banking and Financial Intermediation" (Rimini), and seminar participants at the Banco Central do Brasil, Bank of England, the Board of Governors of the Federal Reserve System, the Bundesbank, CEMFI, the European Central Bank, the Federal Reserve Banks of Philadelphia and New York, Harvard/MIT (Applied Theory), the International Monetary Fund, London Business School, Norges Bank, the Norwegian School of Management, NYU Stern School of Business, and the Universities of Amsterdam, Bonn, Frankfurt, and Warwick for helpful comments. Earlier versions of this paper studied the 23 million bank loans mentioned in the title directly. In this version of the paper, we employ additional data and restructure our specifications. Hence the title is no longer fully accurate, but we retain the title to minimize confusion in past and future citations. We thank Marco lo Duca for excellent research assistance and Katie Jones for professionally editing the manuscript. Ongena acknowledges the hospitality of the European Central Bank and the Swiss National Bank, and Peydró acknowledges the financial support from project ECO201232434 of the Spanish Ministry of Economy and Competitiveness. Any views expressed are those of the authors only and should not be attributed to the Banco de España or the Eurosystem. 
KEYWORDS: Monetary policy, financial stability, credit risk, credit supply composition, bank capital.

\section{INTRODUCTION}

DOES A LOW MONETARY POLICY RATE SPUR RISK-TAKING BY BANKS? Since the severe financial crisis of 2007-2009, this question has been at the center of an intense academic and policy debate. From the start of the crisis in the summer of 2007, market commentators were swift to argue that during the long period of very low interest rates, stretching from 2002 to 2005, banks had softened their lending standards and taken on excessive risk, whereas others argued that low long-term rates and other factors were the culprit. But, at the same time, market participants continuously clamored for central banks to reduce the monetary policy rate to alleviate their financial predicament. Hazardous times for monetary policy indeed. ${ }^{2}$

While the impact of monetary policy on the aggregate volume of credit in the economy has been widely analyzed (Bernanke and Blinder (1992), Kashyap and Stein (2000), Jiménez, Ongena, Peydró, and Saurina (2012)), and changes in the composition of credit in response to changes in the quality of the pool of nonfinancial borrowers-along balance-sheet strength-have been documented (Gertler and Gilchrist (1994)), this paper is the first to empirically study the impact of the monetary policy rate on the composition of the supply of credit, in particular on banks' risk-taking. ${ }^{3}$

Recent theoretical work suggests that expansive monetary policy through the increase in funding provided by households and other agents to banks may cause an increase in risk-shifting in lending, as banks face strong moral hazard problems-especially banks with lower capital amounts at stake, who do not fully internalize loan defaults. ${ }^{4}$ A low short-term interest rate makes riskless

\footnotetext{
${ }^{2}$ Nominal rates were the lowest in several decades and below Taylor rates in many countries, while real rates were negative (Taylor (2007), Rajan (2010), among others, and multiple editorials and op eds in The Wall Street Journal, The Financial Times, and The Economist). Others, notably Bernanke (2010), have argued that low long-term interest rates were more important (than a low monetary policy rate) in driving risk-taking. It is, therefore, important to analyze the impact of both short- and long-term interest rates on bank risk-taking.

${ }^{3}$ Banks are still the main providers of credit in most economies. Credit risk is their most important risk (Kuritzkes and Schuermann (2010)) and any compositional changes in their credit supply directly impact future financial stability and economic growth (Allen and Gale (2007), Matsuyama (2007a)).

${ }^{4}$ Allen and Gale (2000, 2004), Allen and Rogoff (2011), Diamond and Rajan (2012), Borio and Zhu (2008), among others. Adrian and Shin (2011), in the latest Handbook of Monetary Economics, discussed the risk-taking channel of monetary policy. They showed that a lower monetary policy rate increases risk-taking in lending by relaxing the bank capital constraint that is present due to bank moral hazard problems. The idea that the liquidity provided by central banks is important in driving excessive risk-taking is not new, however: "Speculative manias gather speed through expansion of money and credit or perhaps, in some cases, get started because of an initial expansion of money and credit” (Kindleberger (1978, p. 54)).
} 
assets less attractive and may lead to a search for yield by financial intermediaries with short-term time horizons. ${ }^{5}$ Acute agency problems combined with a strong reliance on short-term funding may thus lead the short-term (monetary) interest rate-more than the long-term interest rate-to spur bank risktaking.

Monetary policy rate changes may affect the credit quality of the pool of borrowers through the interest rate channel and the firm balance-sheet channel of monetary policy by changing firm investment opportunities, net worth, and collateral (Bernanke and Gertler (1995)). Moreover, monetary policy, by affecting bank liquidity, may affect the volume of credit supplied through the bank balance-sheet channel of monetary policy (Kashyap and Stein (2000)). Therefore, the decisive identification challenge we address is to disentangle the impact of changes in the monetary policy rate on the composition of the supply of credit from changes in the volume of the supply and changes in the quality and volume of demand, while accounting for the impact of other aggregate variables, including long-term interest rates. Importantly, while the bank balance-sheet channel yields testable predictions at the bank level, and the firm balance sheet and interest rate channels at the firm level, the bank risk-taking channel involves compositional changes in the supply of credit at the bank-firm level.

To meet the identification challenge, we, therefore, turn to the credit register of Spain that contains uniquely comprehensive bank-firm level data on loan applications and outcomes. We access the monthly information on loan applications made to banks by firms since 2002 (matched with the resulting granted loans, and key bank- and firm-level information). ${ }^{6}$ The compiled sample period runs until January 1, 2009, covering both the run-up to and relevant episodes of the western financial crisis. With an economic system dominated by banks and a fairly exogenous monetary policy, Spain offers an ideal setting for identification. As in the literature, we account for the stance of monetary policy with an overnight interest rate.

Our identification strategy consists of three crucial components. First, we employ a two-stage model that explains the monthly granting of loan applications (i.e., on the extensive margin) to firms depending on their ex ante credit risk, followed by the amount of credit committed if the loan applications are

\footnotetext{
${ }^{5}$ See Rajan (2006). On the other hand, higher interest rates may increase the risk-taking incentives of borrowers due to moral hazard (Stiglitz and Weiss (1981)), increase the opportunity costs for banks to hold cash, thus making risky alternatives more attractive (Smith (2002)), or even reduce the banks' net worth or charter value enough to make a "gambling for resurrection" strategy attractive (Keeley (1990)). These countervailing effects make the impact of the short-term interest rate on credit risk-taking ultimately a critical, yet unaddressed, empirical question.

${ }^{6}$ For robustness purposes, we also analyze quarterly bank-firm level records of all outstanding business loan contracts since 1984.
} 
granted (i.e., on the intensive margin). We further analyze other credit outcomes that measure risk, such as the future likelihood of loan default and the absence of collateral requirements.

Second, we progressively saturate specifications with time $*$ firm and time $*$ bank fixed effects to absorb all time-varying, observed and unobserved, firm and bank heterogeneity, which stems from the interest rate and the firm and bank balance-sheet channels. This implies that we analyze the granting of loan applications made by the same firm to different banks in the same period of time, that is, we analyze the supply of credit. To identify bank risk-taking, we interact the changes in the overnight interest rate with a bank capital ratio and an ex ante measure of firm credit risk (based on the firm's credit history). Bank capital is the main theory-based measure for bank agency problems (Holmstrom and Tirole (1997)), but as it may be correlated with other bank characteristics, we also include triple interactions (of the overnight rate and firm risk) with numerous observable bank characteristics. Given the previous two components, we estimate a panel two-stage selection model (a panel type-2 Tobit model in Amemiya's (1985) terminology), where, in the first stage, there is a selection equation that involves the granting of applications and, in the second stage, there are only the credit outcomes for the applications granted. Individual-specific fixed effects that proxy for the firm and bank balance-sheet channels of monetary policy are present in both selection and outcome equations.

Third, we "horserace" the overnight rate-in its interaction with bank capital and firm risk-with corresponding triple interactions of other key macro variables that can also explain risk-taking. The controls added in this way (that may be correlated with the overnight rate) are the changes in Spanish aggregate output and prices, the 10-year government bond rate, bank securitization, and current account deficit (i.e., capital inflows), and a U.S. 10-year government bond rate and the federal funds rate.

We find robust evidence that a lower overnight rate induces lowly capitalized banks to grant more loan applications to ex ante risky firms (than highly capitalized banks), where firm risk is measured with the presence of a bad credit history with nonperforming loans. ${ }^{7}$ When granting applications to these firms (when the overnight rate is lower), lowly capitalized banks further commit more credit and require less collateral, yet their granted loan applications overall face a higher future likelihood of default.

All findings are statistically significant and economically relevant. A decrease of 1 percentage point in the overnight rate, for example, increases the proba-

\footnotetext{
${ }^{7}$ Throughout the paper, we label "lowly capitalized" banks as those that have a lower capitalto-assets ratio than "highly capitalized" banks. We parsimoniously label "risky" firms as those that have a recent credit history with one or more nonperforming loans.
} 
bility that a loan will be granted by a lowly versus a highly capitalized bank (with a difference of 1 standard deviation between them) to a firm with a bad credit history by 8 percent and the resultant committed amount of credit increases by 18 percent, while the future likelihood of loan default of these loans increases by 5 percent and the required collateral decreases by 7 percent. A lower long-term interest rate and other key aggregate bank and macro variables, such as more securitization or higher current account deficits, have no such effects. Importantly, when the overnight rate is lower, virtually all banks grant more credit to firms with higher risk (by around 19 percent for the average bank).

In sum, our estimates suggest that a lower monetary policy rate spurs bank risk-taking and hence that monetary policy affects the composition of the supply of credit beyond the well documented effects of both the bank and firm balance-sheet channels. Consistent with "excessive" risk-taking are our findings that especially banks with less capital "in the game," that is, those afflicted more by agency problems, grant more loan applications and resultant credit to ex ante risky firms, that these banks require less collateral requirements from these firms, and that these banks face more default on their granted loans in the future-all bank actions that accord with risk-shifting.

Our first contribution to the literature is to identify the risk-taking channel of monetary policy. This paper and Ioannidou, Ongena, and Peydró (2009) are the first to concurrently investigate the impact of monetary policy on banks' risk-taking. Ioannidou, Ongena, and Peydró (2009) did not study loan applications or control for unobserved time-varying firm and bank heterogeneity stemming from the firm and bank balance-sheet channels of monetary policyall of which are crucial for the identification of risk-taking (compositional changes of credit supply). Rather, they analyzed the risk pricing by banks in Bolivia during the period 1999-2003. They found that when the U.S. federal funds rate decreases, bank credit risk increases while loan spreads drop. Hence, despite accessing credit registers from different countries, time periods, and monetary policy regimes, and employing different methodologies, both papers find strikingly consistent results. Similarly, ongoing empirical work documents the robust existence and potency of a bank risk-taking channel of monetary policy across many countries and time periods, but also, due to data limitations, none of the papers estimates a selection model on loan applications. ${ }^{8}$

\footnotetext{
${ }^{8}$ See, for example, Altunbas, Gambacorta, and Marquez-Ibañez (2010), Buch, Eickmeier, and Prieto (2010, 2011), Delis, Hasan, and Mylonidis (2011), Paligorova and Santos (2012), Dell'Ariccia, Laeven, and Suarez (2013) for the United States; Gaggl and Valderrama (2010) for Austria; López, Tenjo, and Zárate (2010a, 2010b) for Colombia; Geršl, Jakubík, Kowalczyk, Ongena, and Peydró (2012) for the Czech Republic; and Apel and Claussen (2012) for Sweden.
} 
Our second contribution resides in the identification of the existence of endogenous variation in the composition of the supply of credit. ${ }^{9}$ While the analysis in Matsuyama (2007b) implies compositional changes at a low frequency that depends on the net worth of borrowing firms, the variation in risk in the supply of credit we estimate varies at a high frequency along the monetary cycle and is dependent on the net worth of lending banks, as in Adrian and Shin (2011) and Gertler and Kiyotaki (2011). Our findings are further consistent with mechanisms rooted in moral hazard, such as risk-shifting and search for yield, which undermine financial stability and can lead to the dramatic aggregate consequences witnessed recently.

Our third and final contribution consists in documenting the potential biases that may arise when estimating the credit channel with outstanding credit only. The estimates strikingly demonstrate the additional contribution made by our identification strategy, as without controlling for the first-stage sample bias (i.e., the granting of loan applications), our estimates of risk-taking in the second stage are considerably smaller in absolute value because risk-taking in loan outcomes is not independent from risk-taking in the granting of loan applications (in particular, as we explain later, the correlation between the errors of the first- and second-stage regressions is positive). Similarly, we find that controlling for unobserved time-varying firm heterogeneity (time $*$ firm fixed effects) alters the main coefficients of interest, suggesting nonrandom matching between banks and firms. Our findings, therefore, qualify the estimates in the large credit channel literature that are based on granted credit volume only, either at the macro (as in Bernanke and Blinder (1992)), bank, (as in Kashyap and Stein (2000)), or even the loan level (as in Khwaja and Mian (2008)), and from specifications that do not account well for time-firm heterogeneity.

The rest of the paper proceeds as follows. Section 2 introduces the data sets we analyze. Section 3 explains our empirical identification strategy. Section 4 discusses the results and Section 5 concludes.

\section{DATA SETS: LOAN APPLICATIONS AND CONTRACTS}

We discuss in detail the main data set that contains loan applications and contracts (on the basis of which it is possible to estimate the selection model introduced in the previous section) from Spain, a country with an economic system dominated by banks. ${ }^{10}$

\footnotetext{
${ }^{9}$ Jiménez et al. (2012) used data from the Spanish credit register to assess the potency of the bank lending channel of monetary policy (Bernanke and Blinder (1992), Kashyap and Stein (2000)). In marked contrast, this paper identifies changes in the composition of the supply of credit, in particular with respect to bank risk-shifting. Moreover, the former paper only analyzes loan applications, but not loan outcomes, whereas this paper assesses with a selection model both the extensive and the intensive margins of lending.

${ }^{10}$ Bank deposits (credits) to gross domestic product (GDP) in 2006, for example, equaled 132 percent (164 percent). Most nonfinancial firms had no access to bond financing, and the securi-
} 
The exhaustive bank loan data ${ }^{11}$ to which we have access comes from the Credit Register (CIR) of the Banco de España, which is the supervisor and regulator of the Spanish banking system. The CIR contains confidential and very detailed information at the loan level on virtually all loans granted by all banks operating in Spain, and more than 130,000 firms and 200 banks are active in the database at any moment in time. The CIR is almost comprehensive because the monthly reporting threshold for a loan is only 6,000 euros. Given that we consider only loans to nonfinancial firms, this threshold is very low, which alleviates any concerns about unobserved changes in bank credit to small and medium sized enterprises (which may be more influenced by changes in monetary policy; see for example Gertler and Gilchrist (1994) and Lang and Nakamura (1995)). We match each loan both to bank balance-sheet variables and to selected firm characteristics, notably firm identity and default. Firms with multiple bank relationships account for 86 percent of all business loans and employ on average three banks (which is also the median number), thus enabling identification with time $*$ firm fixed effects.

All banks in Spain automatically receive monthly updated information on the total current credit exposures and (possible) loan defaults-vis-à-vis all banks in Spain —of their own current borrowers. This information is extracted from the CIR. Any bank can also request this information on potential borrowers, which are defined as "any firm that seriously approaches the bank to obtain credit." The monetary cost of requesting this information is zero. But the law stipulates that a bank cannot ask for the information without consent by the potential borrower, indicating a seriousness of intent regarding the "financial relationship between bank and firm."

We observe all requests for information on potential borrowers between 2002:02 and 2008:12 (before 2002 the requests were not stored). Though the requests can be made at any time, they are collated monthly and uniquely link a borrower with a bank. Requests for information on firms that are currently borrowing from the requesting bank would yield information that is already known to this bank. Consequently, requesting information from the CIR is useful if the firm is not currently borrowing from the bank (it has never before received a loan from the bank that is requesting the information or when the relationship between the firm and the bank has already ended). In this way, the loan applications we analyze are on a key category of borrowers who do not simply renew existing or even evergreen loans at their current bank.

For each request we also observe whether the loan is accepted and granted, or not, by matching the loan application database with the CIR database, which

tization of commercial and industrial loans is still very low (4.8 percent in 2006). Delgado, Salas, and Saurina (2007) explained the main features of the Spanish banking system.

${ }^{11} \mathrm{We}$ are not aware of any other country where a credit register is operational that contains records of loan applications to all banks, and that includes lender and borrower identity (and characteristics). 
contains the stock of all loans granted on a monthly basis. Therefore, if multiple banks request information on a particular borrower in the same month, we can infer the bank that granted the loan and the banks that did not. Where a bank requests information but does not grant the loan, either the bank denied the firm credit or-following a revealed preference argument-the firm perceived the offered loan conditions by the bank to be more expensive than those of the loan it eventually took.

Our sample then consists of loan applications by nonfinancial publicly limited and limited liability companies to commercial banks, savings banks, and credit cooperatives. We match the loan applications at a monthly frequency with the bank credit data set to establish which applications are granted and for those that are granted, we then know the committed amount of credit, whether the loan made by the bank to the firm defaults afterward, and whether or not there are collateral requirements. Identification with time $*$ firm fixed effects again results in only those firms that lodge more than one loan application in a particular month during the sample period to be retained, leaving 241,052 different loan applications. ${ }^{12}$ We measure firm credit risk based on past credit performance recorded in the CIR.

\section{IDENTIFICATION STRATEGY}

Does a low monetary policy rate spur risk-taking by banks? To address this question, one needs to disentangle the impact of the changes in the overnight interest rate on the risk of the supply of credit from changes in the volume of the supply, and changes in the quality and the volume of the demand, while accounting for the impact of other key macro variables including long-term interest rates. This bank risk-taking channel involves compositional changes in the supply of credit at the bank-firm level.

Our identification strategy consists of three crucial ingredients: (i) two-stage modeling with first loan applications and then credit outcomes; (ii) saturation with time $*$ firm and time $*$ bank fixed effects, while interacting the change in the overnight interest rate with bank capital and a firm credit-risk measure; (iii) horseracing the overnight interest rate, in its interaction with bank capital and firm risk, with the corresponding triple interactions of other key macro variables. We now discuss each of these three key strategy components in more detail, along with our measures of credit.

\footnotetext{
${ }^{12} \mathrm{We}$ also analyze the records on all granted business lending for the entire 1988:II-2008:IV period that covers two business cycles (to construct the firms' credit histories we use the data available since 1984). The analysis on this extended sample mainly captures the monitoring of existing clients, rather than the screening of loan applications by new ones. We aggregate the information available in the CIR to more than 50,000,000 quarter-bank-firm credit exposure triplets (henceforth "loans"). We randomly sample 20 percent of the firms to meet computational constraints. Once a firm is selected, all its loans are included, yielding a sample with 6,564,964 granted loans. We present the estimates later in robustness.
} 


\subsection{Two-Stage Model}

Our benchmark specification is a selection model, with the granting of loan applications in the first stage and, if the application is not rejected and the loan is granted, the credit amount the bank commits in the second stage. When supplying credit, the two key steps taken by banks are the granting of loan applications and the committing of loan amounts, that is, the extensive and intensive margins of lending, respectively. With the second stage, the future likelihood of default and collateral requirements will also be analyzed.

\subsection{Saturation With Fixed Effects and Triple Interactions}

\subsubsection{Time $*$ Firm and Time $*$ Bank Fixed Effects}

Given that the majority of banks are affected by moral hazard problems (little capital at stake), the risk-taking channel implies that expansionary monetary policy spurs banks into risky lending. However, this testable prediction can also be consistent with demand channels, in particular, with the firm balance sheet and the interest rate channel of monetary policy (Bernanke and Gertler (1995)). Therefore, to suppress concurrent changes in the quality (along balance-sheet strength, as risky firms may have improved their net worth, investment opportunities, and collateral values) and volume of the firm demand for credit, we saturate our benchmark specifications with time $*$ firm fixed effects. Observed and unobserved time-varying firm characteristics that are accounted for in this way include the net present value of firm projects, investment opportunities, agency problems, risk, pledgeable income, and collateral. Identification comes from comparing changes in lending in the same month by different banks (with respect to their capital-to-asset ratios) to the same firm. Most firms apply to multiple banks and, similarly, maintain multiple bank relationships. Indeed firms with multiple bank relationships account for 86 percent of all business loans. So the loss of observations for the exhaustive data set we study is minimal.

We also add time $*$ bank fixed effects to our benchmark specification to suppress concurrent changes in the volume of the supply of credit and to further identify its compositional shift. This is not our benchmark specification as it is not as crucial as time $*$ firm effects to identify risk-taking, we lose significant time variation in banks, and Kashyap and Stein (2000) do not include bank fixed effects in their analysis of the bank lending channel of monetary policy. With observed and unobserved time-varying bank heterogeneity accounted for, identification resides in comparing changes in lending during the same month by the same bank to firms that differ in credit risk.

\subsubsection{Model Estimation}

Our economic application is, therefore, a panel-data version of the classic sample-selection model of Heckman (1979), with-in the second stage 
only-observable loan outcomes for the applications granted. Consequently, we need to estimate a panel type-2 Tobit model (in the terminology introduced by Amemiya (1985)). We can estimate the first-stage regression in a straightforward way. However, in the second stage, there are two potential biases: a sample selection bias from the granting of loan applications and the presence of unobserved heterogeneity. The sample selectivity induces a fundamental nonlinearity in the equation of interest with respect to the unobserved characteristics, which, in contrast to a linear panel setup, cannot be differenced away. This is because the sample selection effect, which enters additively in the main equation, is a (generally unknown) nonlinear function of both the observed time-varying regressors and the unobservable individual effects of the selection equation. It is, therefore, not constant over time.

Wooldridge (1995) and others (see also Cameron and Trivedi (2005) and Wooldridge (2010)) proposed methods for correcting the bias by the parameterization of the sample selection mechanism. For large data sets, such as the one to which we have access, one does not need to parameterize by using the more flexible alternative method proposed by Kyriazidou (1997) (see also Honoré, Kyriazidou, and Powell (2000) and Arellano and Honoré (2001)). The method for estimating the main regression equation of interest follows the familiar two-step approach proposed by Heckman (1974). In the first step, the unknown coefficients of the selection equation are consistently estimated. In the second step, these estimates are used to estimate the equation of interest by a weighted least squares regression: the fixed effects from the main equation are eliminated by taking differences on the observed selected variables, while the first-step estimates are used to construct the weights whose magnitudes depend on the size of the sample selection bias. ${ }^{13}$

\footnotetext{
${ }^{13}$ The basic assumption in Kyriazidou (1997) to difference out the fixed effects and the sample selection bias is the conditional exchangeability assumption. This assumption in our economic application pertains to the errors for the set of applications made within the same month by the same firm to different banks. The assumption implies that, conditional on the large set of fixed effects that we include, the errors are identically distributed for the granting decisions made by the banks (although the errors can have correlations that are different from zero). Given that we only use applications from firms to new banks and given that the banks are ordered randomly in our data set, it is reasonable to assume that, conditional on the large set of fixed effects, the aforementioned errors have the same distribution as the exchangeability assumption implies. Hence within month $t$ for firm $i$ and two contiguous banks $b$ and $b+1$, differentiating out is similar for $e(t, i, b+1)-e(t, i, b)$ and $e(t, i, b)-e(t, i, b+1)$. This assumption is substantially less stringent than the parameterization of the unobserved heterogeneity and errors using alternative methods. For example, Wooldridge (1995) implied a main assumption of conditional mean independence and the normality distribution of the error of the selection equation, whereas Kyriazidou (1997) did not imply these strong assumptions. In fact, Wooldridge (2010) compared his method with Kyriazidou's as follows: "The preceding methods assume normality of the errors in the selection equation and, implicitly, the unobserved heterogeneity. Kyriazidou (1997) and Honoré and Kyriazidou (2000) have proposed methods that do not require distributional assumptions" (op. cit. p. 836). As we have access to a large data set and the assumptions in Kyriazidou (1997) are substantially weaker, Kyriazidou (1997) is superior. However, we also estimate the results based on
} 


\subsubsection{Triple Interaction of Overnight Interest Rate, Bank Capital Ratio, and Firm Credit Risk}

Given the set of fixed effects, identification of the risk-taking channel comes from exploiting the testable prediction that when the monetary policy rate is lower, banks that are subject to more severe agency problems lend more riskily. Therefore, it is essential to have a sharp measure for the intensity of the agency conflict that besets banks' own borrowing from their financiers. The bank capital-to-assets ratio is such a measure (Holmstrom and Tirole (1997)). ${ }^{14}$ The ratio is particularly meaningful in Spain because off-balance-sheet activity by banks has been almost nonexistent. ${ }^{15}$

To identify the risk-taking channel of monetary policy, we interact the change in the overnight interest rate with the lagged bank capital ratio (in the spirit of Kashyap and Stein (2000)) and a measure of firm credit risk. Our mainstay measure of firm credit risk is a variable that equals 1 if a firm had any nonperforming loans outstanding during a 4-year period prior to applying or borrowing, and equals 0 otherwise. Recent nonperformance is also relevant for banks, so in robustness we assess shorter prior time periods (i.e., comprising 3, 2, and 1 years) and further also study a 5-year period. ${ }^{16}$

As bank capital may be correlated with other bank characteristics, we also add (besides time $*$ bank fixed effects) the corresponding triple interactions (i.e., in which bank capital is replaced) with bank size, liquidity, profitability, nonperforming loan ratio, and type (i.e., commercial bank, savings bank, and credit cooperative). Triple interactions of the inflation rate and firm credit risk with all these bank variables (excluding type) control exhaustively for changes in the price level (i.e., to arrive at a real overnight interest rate) in robustness. ${ }^{17}$

\footnotetext{
Wooldridge (1995) and the results are very similar (see Table A.II in the Supplemental Material (Jimenez, Ongena, Peydro, and Saurina (2014)).

${ }^{14}$ Stiglitz and Greenwald (2003) conjectured similarly that banks may act risk aversely because of information, contract, and competition imperfections. Consequently, the degree of their risk aversion may depend not only on their borrowers', but also on their own net worth. A lower monetary policy rate increases the value of the banks' portfolio of securities and loans, thereby raising banks' net worth and capital, especially for the lowly capitalized banks. This, in turn, increases their ability and incentives to take credit risk and this effect may be most strongly felt by the lowly capitalized banks.

${ }^{15}$ Consequently, total bank assets cover most of the banks' businesses. Banks did not develop conduits or structured investment vehicles (SIVs) because the prevailing accounting and regulatory rules made banks consolidate these items and set aside sufficient capital (see also Acharya and Schnabl (2009)).

${ }^{16}$ We focus on a 4-year period to maintain consistency, that is, the sample period in our robustness exercises starts in mid-1988 when the Spanish exchange rate regime changed, and the credit register has records as of 1984; the pre-1988 records are then needed to construct firm credit histories. For the loan application data set, we can also study 5-year periods.

${ }^{17}$ Given the extensive sets of fixed effects we include and as we are primarily interested in the estimated coefficients on the triple interactions (as the next sections explain), we employ linear probability models. Results in the second stage do not change if, in the first stage, we use a
} 
In accordance with the focus of our analysis and the variation in our data, we multicluster standard errors at the time, bank, and firm level.

\subsection{Horseracing Triple Interactions}

\subsubsection{The Overnight Interest Rate}

Banks are mostly funded by short-term debt, the interest rates of which will likely respond to changes in the monetary policy rate. As in Kashyap and Stein (2000), we employ an overnight interest rate, that is, the Euro Overnight Index Average rate (EONIA), which is targeted by the European Central Bank (ECB) and the Eurosystem. ${ }^{18}$

For the whole period, short-term interest rates in Spain were decided in Frankfurt, not in Madrid, ${ }^{19}$ assuaging concerns of reverse causality (e.g., future higher risk may imply current monetary expansion) and omitted variables (variables correlated with the stance of monetary policy that can also influence risk-taking). Further mitigating these concerns, time $*$ firm and time $*$ bank fixed effects absorb any observed and unobserved time-varying heterogeneity across all included firms and banks (comprising, for all practical purposes, the entire economy). In addition, as the sample of loan applications starts only after the introduction of the euro in 1999, no major structural changes in the Spanish economy are included in our main analysis.

\subsubsection{Long-Term Interest Rates and Other Key Macro Variables}

Despite the predominance of banks' short-term funding, their risk-taking could also be affected by changes in long-term interest rates and other key

nonlinear model. To make results comparable across specifications, all samples contain only firms that apply to multiple banks.

${ }^{18}$ Before 1999, we use the Spanish overnight interest rate for the sample of all business loans analyzed in robustness.

${ }^{19}$ Even during the robustness sample period, monetary policy was decided in Frankfurt. In 1986, Spain joined the European Union. Consequently, monetary policy started to pay more attention to the exchange rate with the deutsche mark. At the same time, capital restrictions were being eliminated. Implicitly from mid-1988, and explicitly from 1989 when Spain joined the European Monetary System and its exchange rate mechanism, the exchange rate target with the deutsche mark was the main objective of its monetary policy (Banco de España (1997)). Hence as of mid-1988, Spanish monetary policy was no longer independent from German monetary policy according to the textbook Mundell-Fleming Trilemma (Krugman and Obstfeld (2006)). From 1999 onwards, Spain joined the Eurosystem, representing around 10 percent of the total economic activity in this group. Notice that the mandate given to both the Bundesbank and the ECB was primarily to preserve price stability, not to stimulate economic activity or safeguard financial stability. Moreover, interest rate changes and GDP growth are not highly correlated in Spain because of the relatively low level of synchronization of economic activity in Spain vis-à-vis the largest Euro area countries, even after 1999 (Giannone, Lenza, and Reichlin (2010)). 
macro variables. Hence, the third crucial component in our identification strategy is to concurrently account for the effects of changes in the long-term interest rate (which may also capture firm investment opportunities and pledgeable income, which often are long-term in nature) and other aggregate variables. Therefore, we horserace the triple interaction between the Spanish 10-year government bond rate, bank capital, and firm risk, with the equivalent triple interaction with the monetary policy rate. Similar triples with the changes in GDP growth and prices-as the main determinants of the monetary policy rate-are also in the race.

We also concurrently include triple interactions with other aggregate variables for bank risk-taking such as changes in securitization and current account deficit (capital inflows), and U.S. 10-year government bond and federal funds rates, respectively, the latter possibly kept low by a savings glut and the deepening of financial globalization. Given their correlation with the overnight rate, all these macro variables in triples also feature as controls, to the extent that the time $*$ firm and time $*$ bank fixed effects did not already soak up relevant macroeconomic variation.

Given our comprehensive data, sample periods, identification strategy, and saturated specifications, we are confident that it is possible to make well founded inferences on whether short-term monetary policy rates affect banks' credit risk-taking and, in general, on whether macroeconomic shocks result in changes in the composition of the supply of credit.

\section{RESULTS}

\subsection{Model Lineup}

This section presents and discusses our estimates. We estimate selection models with loan applications in the first stage and, for the applications granted, the amount of committed loans (or other dependent variables) in the second stage. To stepwise saturate with fixed effects and make robust inferences, we employ a linear probability model in the first stage.

The sample period goes from 2002:02 to 2008:12 and includes 65 months of run-up to and 18 months of financial crisis. The total number of loan applications equals 241,052 (Table I presents the summary statistics). To make results comparable across specifications, the sample contains only firms that apply to multiple banks.

\subsection{Dependent Variables}

The dependent variable in the first-stage regression in Tables II-VI is $I$ (LOAN APPLICATION IS GRANTED $\left.{ }_{t b i}\right)$, which equals 1 if the loan application made in month $t$ to bank $b$ by firm $i$ is successful and the loan is granted in $t$ to $t+3$, and equals 0 otherwise (all variable definitions are provided in 
TABLE I

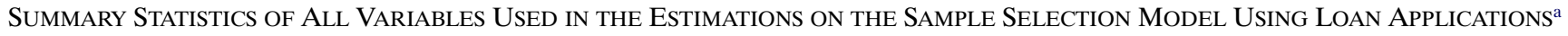

\begin{tabular}{|c|c|c|c|c|c|c|c|}
\hline Variable Name & Mean & Minimum & Q1 & Median & Q3 & Maximum & Standard Deviation \\
\hline $\begin{array}{l}\text { Dependent Variables } \\
I\left(\text { GRANTING OF LOAN APPLICATIONS }_{t b i}\right) \\
\text { COMMITTED AMOUNT OF GRANTED LOANS }_{t b i} \\
\left.\text { LN(CREDIT AMOUNT }_{t b i}\right) \\
I\left(\text { FUTURE DEFAULT }_{t b i}\right) \\
\left.I \text { (WITHOUT COLLATERAL }_{t b i}\right)\end{array}$ & $\begin{array}{c}0.36 \\
287 \\
4.41 \\
0.35 \\
0.89\end{array}$ & $\begin{array}{l}0 \\
2 \\
0.69 \\
0 \\
0\end{array}$ & $\begin{array}{l}0 \\
30 \\
3.40 \\
0 \\
1\end{array}$ & $\begin{array}{l}0 \\
69 \\
4.23 \\
0 \\
1\end{array}$ & $\begin{array}{l}1 \\
180 \\
5.19 \\
1 \\
1\end{array}$ & $\begin{array}{c}1 \\
77,704 \\
11.26 \\
1 \\
1\end{array}$ & $\begin{array}{l}0.48 \\
1315 \\
1.32 \\
0.48 \\
0.31\end{array}$ \\
\hline $\begin{array}{l}\text { Independent Variables } \\
\text { Firm Credit Risk Variables } \\
\text { Firm Credit Risk Variable With } 4 \text { Years Horizon } \\
\quad \text { I(FIRM RISK } \\
\text { (FI) }\end{array}$ & 0.03 & 0 & 0 & 0 & 0 & 1 & 0.17 \\
\hline $\begin{array}{l}\text { Firm Credit Risk Variables With Other Horizons } \\
\left.\text { I(FIRM RISK } 5 \text { YEARS }_{t i}\right) \\
\left.\text { I(FIRM RISK } 3 \text { YEARS }_{t i}\right) \\
\left.\text { I(FIRM RISK } 2 \text { YEARS }_{t i}\right) \\
\left.\text { I(FIRM RISK } 1 \text { YEAR }_{t i}\right)\end{array}$ & $\begin{array}{l}0.03 \\
0.03 \\
0.02 \\
0.02\end{array}$ & $\begin{array}{l}0 \\
0 \\
0 \\
0\end{array}$ & $\begin{array}{l}0 \\
0 \\
0 \\
0\end{array}$ & $\begin{array}{l}0 \\
0 \\
0 \\
0\end{array}$ & $\begin{array}{l}0 \\
0 \\
0 \\
0\end{array}$ & $\begin{array}{l}1 \\
1 \\
1 \\
1\end{array}$ & $\begin{array}{l}0.17 \\
0.16 \\
0.14 \\
0.12\end{array}$ \\
\hline $\begin{array}{l}\text { Macro Variables } \\
\quad \Delta \text { OVERNIGHT RATE }_{t-1} \\
\quad \Delta \mathrm{GDP}_{t-1} \\
\quad \Delta \mathrm{CPI}_{t-1}\end{array}$ & $\begin{array}{l}0.26 \\
3.19 \\
3.41\end{array}$ & $\begin{array}{r}-1.52 \\
-0.27 \\
2.14\end{array}$ & $\begin{array}{r}-0.08 \\
3.00 \\
2.67\end{array}$ & $\begin{array}{l}0.23 \\
3.46 \\
3.47\end{array}$ & $\begin{array}{l}0.74 \\
3.83 \\
4.03\end{array}$ & $\begin{array}{l}1.48 \\
3.98 \\
5.27\end{array}$ & $\begin{array}{l}0.71 \\
0.88 \\
0.80\end{array}$ \\
\hline $\begin{array}{l}\text { Bank Variables } \\
\text { Bank Risk-Taking Variable } \\
\text { BANK CAPITAL }_{t-1 b} \\
\left.\text { LN(BANK CAPITAL }_{t-1 b}\right)\end{array}$ & $\begin{array}{l}5.51 \\
1.66\end{array}$ & $\begin{array}{l}3.18 \\
1.16\end{array}$ & $\begin{array}{l}4.20 \\
1.44\end{array}$ & $\begin{array}{l}4.94 \\
1.60\end{array}$ & $\begin{array}{l}6.09 \\
1.81\end{array}$ & $\begin{array}{r}63.10 \\
4.14\end{array}$ & $\begin{array}{l}1.96 \\
0.30\end{array}$ \\
\hline $\begin{array}{l}\text { Bank Controls } \\
\text { LN(TOTAL ASSET } \\
\left.\text { LIQUIDITY RATIO }_{t-1 b}\right) \\
\text { ROA }_{t-1 b} \\
\text { NPL RATIO }_{t-1 b} \\
\text { I(COMMERCIAL BANK } \\
\left.\text { I } \text { (SAVINGS BANK }_{b}\right)\end{array}$ & $\begin{array}{r}17.33 \\
14.96 \\
0.98 \\
0.90 \\
0.39 \\
0.54\end{array}$ & $\begin{array}{r}9.94 \\
0.03 \\
-8.93 \\
0.00 \\
0 \\
0\end{array}$ & $\begin{array}{l}16.34 \\
9.59 \\
0.68 \\
0.36 \\
0 \\
0\end{array}$ & $\begin{array}{c}17.37 \\
13.94 \\
0.92 \\
0.62 \\
0 \\
1\end{array}$ & $\begin{array}{l}18.50 \\
18.87 \\
1.17 \\
1.03 \\
1 \\
1\end{array}$ & $\begin{array}{l}19.91 \\
91.21 \\
10.84 \\
16.08 \\
1 \\
1\end{array}$ & $\begin{array}{l}1.45 \\
7.52 \\
0.53 \\
0.89 \\
0.49 \\
0.50\end{array}$ \\
\hline
\end{tabular}

${ }^{a}$ This table reports summary statistics for the sample with 241,052 observations from the 2002:02-2008:12 period. To improve the readability of the estimated coefficients, we divide the $\triangle$ OVERNIGHT RATE by 100 in all subsequent estimations. 
the Appendix). Its mean of 0.36 (in Table I) implies 2.8 applications lodged per loan granted, with a standard deviation of 0.48 .

The dependent variable in the second-stage regression in Tables II-IV is LN(CREDIT AMOUNT AMi $_{t}$ ), which, following a granted application in month $t$ to bank $b$ by firm $i$, equals the logarithm of the committed loan amount (in thousands of euros) granted by bank $b$ to firm $i$ in $t$ to $t+3$. The mean and standard deviation are 4.41 and 1.32, equivalent to around 82,000 and 3,750 euros, respectively.

\subsection{Two-Stage Model}

Our initial main inferences on risk-taking (triple interactions) are based on the following parsimonious specification, which is model (4) in Table II:

$$
\begin{aligned}
& \text { I(LOAN APPLICATION IS GRANTED } \left.{ }_{t b i}\right) \\
& =\alpha_{t}+\alpha_{i}+\alpha_{b}+\beta I\left(\mathrm{FIRM} \mathrm{RISK}_{t i}\right) \\
& +\delta \Delta \text { OVERNIGHT RATE }_{t-1} * I\left(\text { FIRM RISK }_{t i}\right) \\
& +\gamma \Delta \text { OVERNIGHT RATE }_{t-1} * \text { LN }\left(\text { BANK CAPITAL }_{t-1 b}\right) \\
& * I\left(\text { FIRM RISK }_{t i}\right)+\text { Controls }_{t b i}+\varepsilon_{t b i}, \\
& \text { LN(CREDIT AMOUNT } \left.\text { A }_{t b i}\right) \\
& =\alpha_{t}+\alpha_{i}+\alpha_{b}+\beta^{\prime} I\left(\text { FIRM RISK }_{t i}\right) \\
& +\delta^{\prime} \Delta \text { OVERNIGHT RATE }_{t-1} * I\left(\text { FIRM RISK }_{t i}\right) \\
& +\gamma^{\prime} \Delta \text { OVERNIGHT RATE }_{t-1} * \text { LN }\left(\text { BANK CAPITAL }_{t-1 b}\right) \\
& * I\left(\text { FIRM RISK }_{t i}\right)+\text { Controls }_{t b i}+\varepsilon_{t b i},
\end{aligned}
$$

where $I$ (FIRM RISK FI $_{t}$ ) equals 1 if in month $t$ firm $i$ had nonperforming loans outstanding in the previous 4 years prior to $t,{ }^{20} \Delta$ OVERNIGHT RATE $_{t-1}$ is the annual change in the Euro Overnight Index Average rate (EONIA) at $t-1$, and $\mathrm{LN}\left(\mathrm{BANK} \mathrm{CAPITAL}_{t-1 b}\right)$ is the capital ratio at time $t-1$ defined as the logarithm of the ratio of bank equity and retained earnings over total assets of bank $b$. Firm risk has a mean equal to 3 and a standard deviation of 17 percent, the overnight rate change has a mean equal to 0.26 and standard deviation of 0.71 percentage points, and bank capital has a mean of 1.66 and standard deviation of 0.30 percent. $^{21}$

\footnotetext{
${ }^{20}$ Following common practice, we classify loans that are 90 days overdue as "nonperforming," which includes "doubtful" loans, where banks expected firms to overcome their temporary difficulties in repaying.

${ }^{21}$ There is actually little or no correlation between the capital ratio of the banks that the firms apply to borrow from and firm credit risk (correlations range between 0.005 and 0.006). Also
} 
MAIN RESULTS ${ }^{\mathrm{a}}$

\begin{tabular}{|c|c|c|c|c|c|c|}
\hline & \multirow[t]{2}{*}{ (1) } & \multirow[t]{2}{*}{ (2) } & \multirow[t]{2}{*}{ (3) } & \multirow[t]{2}{*}{ (4) } & $(5)$ & $(6)$ \\
\hline & & & & & \multicolumn{2}{|c|}{ BENCHMARK TIME*BANK FE } \\
\hline \multicolumn{7}{|l|}{ FIRST STEP } \\
\hline \multicolumn{7}{|l|}{ Dependent Variable: I GRANTING OF LOAN APPLICATIONS $\left._{t b i}\right)$} \\
\hline$I\left(\right.$ FIRM RISK $\left._{t i}\right)$ & $\begin{array}{l}-0.04^{* * *} \\
(0.01)\end{array}$ & $\begin{array}{l}-0.04^{* * *} \\
(0.01)\end{array}$ & $\begin{array}{l}-0.04^{* * *} \\
(0.01)\end{array}$ & $\begin{array}{l}-0.06^{* * *} \\
(0.02)\end{array}$ & & \\
\hline$\Delta$ OVERNIGHT RATE $_{t-1} * I\left(\right.$ FIRM RISK $\left._{t i}\right)$ & $(1.22)$ & $\begin{array}{l}-2.65^{* *} \\
(1.53)\end{array}$ & $\begin{array}{r}-2.62^{*} \\
(2.37)\end{array}$ & 1.26 & & \\
\hline 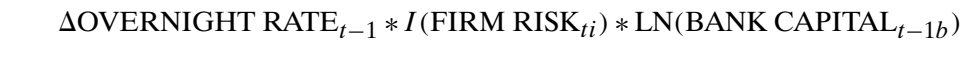 & & & & $\begin{array}{r}6.97^{*} \\
(4.12)\end{array}$ & $\begin{array}{l}9.89^{* *} \\
(4.72)\end{array}$ & $\begin{array}{r}9.73^{*} \\
(5.59)\end{array}$ \\
\hline \multicolumn{7}{|l|}{ Impact of 1 pp Decrease in Overnight Rate on Granting to Risky Firms } \\
\hline - By the Mean Bank & & $7.4 \%$ & $7.4 \%$ & $-3.5 \%$ & & \\
\hline - By Lowly versus Highly Capitalized Bank (1 St. Dev. Difference) & & & & $5.9 \%$ & $8.4 \%$ & $8.2 \%$ \\
\hline \multicolumn{7}{|l|}{ 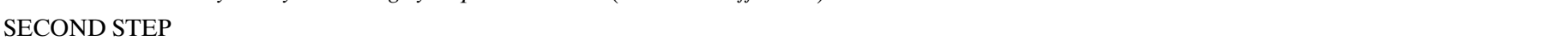 } \\
\hline \multicolumn{7}{|l|}{ Dependent Variable: LN(CREDIT AMOUNT $t b i)$} \\
\hline$I\left(\mathrm{FIRM} \mathrm{RISK}_{t i}\right)$ & $\begin{array}{l}-0.23^{* * *} \\
(0.08)\end{array}$ & $\begin{array}{c}-0.17^{* *} \\
(0.08)\end{array}$ & $\begin{array}{r}-0.15 \\
(0.10)\end{array}$ & $\begin{array}{r}-0.30 \\
(0.24)\end{array}$ & & \\
\hline$\Delta$ OVERNIGHT RATE $_{t-1} * I\left(\right.$ FIRM RISK $\left._{t i}\right)$ & & $\begin{array}{l}-27.39^{* * *} \\
(9.93)\end{array}$ & $\begin{array}{r}-25.68^{*} \\
(13.14)\end{array}$ & $\begin{array}{r}-62.59^{*} \\
(37.51)\end{array}$ & & \\
\hline 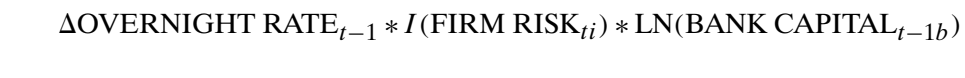 & & & & $\begin{array}{l}59.56^{* *} \\
(25.41)\end{array}$ & $\begin{array}{l}58.94^{* *} \\
(24.96)\end{array}$ & $\begin{array}{l}53.49^{+} \\
(32.62)\end{array}$ \\
\hline Impact of 1 pp Decrease in Overnight Rate on Credit to Risky Firms & & & & & & \\
\hline $\begin{array}{r}- \text { By the Mean Bank } \\
\text { - By Lowly versus Highly Capitalized Bank (1 St. Dev. Difference) }\end{array}$ & & $27.4 \%$ & $25.7 \%$ & $\begin{array}{l}62.6 \% \\
18.0 \%\end{array}$ & $17.8 \%$ & $16.1 \%$ \\
\hline Total Impact of 1 pp Decrease in Overnight Rate on Credit to Risky Firms & & & & & & \\
\hline- By the Mean Bank & & $19.8 \%$ & $19.2 \%$ & $18.0 \%$ & & \\
\hline - By Lowly versus Highly Capitalized Bank (1 St. Dev. Difference) & & & & $14.6 \%$ & $18.5 \%$ & $17.8 \%$ \\
\hline
\end{tabular}


TABLE II-Continued

\begin{tabular}{|c|c|c|c|c|c|c|}
\hline & (1) & (2) & (3) & (4) & (5) & (6) \\
\hline & & & & & BENCHMARK & TIME*BANK FE \\
\hline (Year-Month) Fixed Effects & Yes & Yes & Yes & Yes & - & - \\
\hline Firm Fixed Effects & No & No & No & Yes & - & - \\
\hline Bank Fixed Effects & No & No & Yes & Yes & Yes & - \\
\hline [(Year-Month)*Firm] Fixed Effects & No & No & No & No & Yes & Yes \\
\hline [(Year-Month)*Bank] Fixed Effects & No & No & No & No & No & Yes \\
\hline Bank Controls & Yes & Yes & Yes & Yes & Yes & - \\
\hline$\left\{\Delta \mathrm{GDP}_{t-1}, \Delta \mathrm{CPI}_{t-1}\right\} * I\left(\right.$ FIRM RISK $\left._{t i}\right) * \mathrm{LN}\left(\right.$ BANK CAPITAL $\left._{t-1 b}\right)$ & No & No & No & Yes & Yes & Yes \\
\hline$\Delta$ OVERNIGHT RATE $_{t-1} * I\left(\right.$ FIRM RISK $\left._{t i}\right) *\left\{\right.$ Bank Controls $\left._{t-1 b}\right\}$ & No & No & No & Yes & Yes & Yes \\
\hline
\end{tabular}

${ }^{a}$ This table reports estimates from type-2 Tobit sample selection models, which explain the probability that a loan application is approved by a bank and the loan is granted to a firm that is new to the bank (extensive margin of new lending) and the committed amount of granted loans by the bank to a firm given its loan application was successful (intensive margin of new lending). The estimates of the first step in this table come from linear probability models using ordinary least squares and 241,052 observations from the 2002:02-2008:12 period. The estimates of the second step come from the second stage of a two-step estimation procedure for panel data sample selection models outlined by Kyriazidou (1997) using kernel least squares. It uses 38,334 observations. The dependent variables are $I$ (GRANTING OF LOAN APPLICATIONS (Gi ), which equals 1 if the loan application made in month $t$ to bank $b$ by firm $i$ is successful and the loan is granted in $t$ to $t+3$, and equals 0 otherwise; and LN(CREDIT AMOUNT $t b i$ ), which following a successful application filed in month $t$ to bank $b$ by firm $i$ is the logarithm of the committed loan amount granted by bank $b$ to firm $i$ in $t$ to $t+3$. The definition of the independent variables can be found in the Appendix (FIRM RISK is based on a 4-year credit history). Where possible, a constant is included but its coefficient is left unreported. When firm fixed effects are not included, firm observables are included; see the main text. Where possible, all macro, bank, and firm variables in triple interactions are included in levels and in double interactions but their coefficients are left unreported. Fixed effects are either included ("Yes"), not included ("No"), or spanned by another set of effects ("-—"). For each variable the first row lists the coefficient, the second row lists the robust standard error that is corrected for multiclustering at the year-month, bank and firm level; the corresponding significance levels are adjacent to the coefficient in the second column. The single-stage/total impact is calculated as the percent change in the mean granting probability or/times the credit amount following a one percentage point decrease in the overnight interest rate and lending to firms with doubtful loans in the previous four years by a mean bank or by a lowly versus highly capitalized bank that differ by one standard deviation in capitalization. ${ }^{+}$The coefficient has a $p$-value that equals 10.1 percent. ${ }^{*} p<0.10 ; * * p<0.05 ; * * * p<0.01$ 
We are interested in the six coefficients, that is, $\beta^{(\prime)}, \delta^{(\prime)}$, and $\gamma^{(\prime)}$, on firm risk and its double and triple interactions with the overnight rate, and the overnight rate and bank capital. The specification further loads in time, firm, and bank fixed effects (represented by $\alpha_{t}, \alpha_{i}$, and $\alpha_{b}$ ), and as controls includes the following sets of variables: (i) firm risk and bank capital, size, liquidity, profitability, nonperforming loan ratio, and type; (ii) the interaction between the overnight rate and bank capital; and (iii) the triple interactions of the change in GDP and inflation, respectively, with bank capital and firm risk. We also perform an initial analysis without the triple interaction, analyzing only the double interaction on firm risk and overnight rate.

In subsequent specifications we sequentially add effects and controls to arrive at model (6) in Table III. This is the most saturated specification that fields time $*$ firm and time $*$ bank fixed effects, $\alpha_{t i}$ and $\alpha_{t b}$, that are comprehensive sets of 110,545 dummies for each time-firm pair and 6856 dummies for each timebank pair, and fields bank controls, triples with other macro and bank variables (to be listed in detail later), and the doubles and the levels of all variables in the triples when those are not absorbed by the fixed effects: ${ }^{22}$

$$
\begin{aligned}
& I\left(\text { LOAN APPLICATION IS GRANTED }_{t b i}\right) \\
& =\alpha_{t i}+\alpha_{t b} \\
& \left.+\gamma \Delta \text { OVERNIGHT RATE }_{t-1} * \text { LN(BANK } \text { CAPITAL }_{t-1 b}\right) \\
& \text { * I (FIRM RISK } \left.{ }_{t i}\right) \\
& + \text { Controls }_{t b i}+\varepsilon_{t b i}, \\
& \text { LN(CREDIT AMOUNT } \left.\text { AMi }_{t}\right) \\
& =\alpha_{t i}+\alpha_{t b} \\
& +\gamma^{\prime} \Delta \text { OVERNIGHT RATE }_{t-1} * \text { LN }\left(\text { BANK CAPITAL }_{t-1 b}\right) \\
& \text { * I (FIRM RISK } \left.{ }_{t i}\right) \\
& + \text { Controls }_{t b i}+\varepsilon_{t b i} \text {. }
\end{aligned}
$$

notice that the mean (median) capital ratio equals 6.1 percent (5.4 percent), with a standard deviation that equals only 2.3 percent. But the ratio ranges between 0.3 and 92.5 percent; hence, we take its logarithm to have a more normal symmetric distribution, in turn also reducing the impact of the few high-value observations and accounting for the possibly decreasing marginal effect on risk-taking of increasingly higher capital ratios. Results are robust if we use the bank capital ratio without taking its logarithm.

${ }^{22}$ If thus used as controls, we do not report their estimated coefficients in the tables to avoid unnecessary clutter. 
TABLE III

VARIOUS ROBUSTNESS ${ }^{\mathrm{a}}$

\begin{tabular}{|c|c|c|c|c|c|c|}
\hline & (1) & (2) & (3) & (4) & (5) & (6) \\
\hline & $\begin{array}{l}\text { BENCHMARK }+ \\
\Delta \text { CPI }_{t-1} \text { IN ALL } \\
\text { INT'ACTIONS }^{-1}\end{array}$ & $\begin{array}{l}\text { BENCHMARK+ } \\
\Delta \text { SPANISH } \\
\text { LONG-TERM } \\
\text { INTEREST } \\
\text { RATE }\end{array}$ & $\begin{array}{c}\text { BENCHMARK+ } \\
\Delta \text { U.S. SHORT } \\
\text { (LONG) } \\
\text { TERM } \\
\text { INTEREST } \\
\text { RATE }\end{array}$ & $\begin{array}{c}\text { BENCHMARK+ } \\
\Delta \text { SPANISH } \\
\text { SECURITIZED } \\
\text { ASSETS/TOT. } \\
\text { ASSETS }\end{array}$ & $\begin{array}{l}\text { TIME*BANK FE+ } \\
\text { CTRLS OF (4) \& } \\
\text { A.III (5) \& (6) }\end{array}$ & $\begin{array}{c}\text { TIME*BANK FE } \\
\text { NO } \\
\text { CORRECTION } \\
\text { FOR SAMPLE } \\
\text { SELECTION: } \\
\text { ONE-STEP }\end{array}$ \\
\hline \multicolumn{7}{|l|}{ FIRST STEP } \\
\hline $\begin{array}{l}\text { Dependent Variable: } I\left(\text { GRANTING OF LOAN APPLICATIONS }_{t b i}\right) \\
\quad \Delta \text { OVERNIGHT RATE }_{t-1} * I\left(\text { FIRM RISK }_{t i}\right) * \text { LN }\left(\text { BANK CAPITAL }_{t-1 b}\right)\end{array}$ & $\begin{array}{l}9.34^{* *} \\
(4.68)\end{array}$ & & $\begin{array}{l}10.86^{* *} \\
(4.58)\end{array}$ & $\begin{array}{l}10.05^{* *} \\
(4.64)\end{array}$ & $\begin{array}{l}10.82^{*} \\
(5.75)\end{array}$ & \\
\hline CONTROL $_{t-1} * I\left(\right.$ FIRM RISK $\left._{t i}\right) *$ LN $\left(\right.$ BANK CAPITAL $\left._{t-1 b}\right)$ & & $\begin{array}{c}3.41 \\
(6.04)\end{array}$ & $\begin{array}{l}4.67^{*} \\
(2.73)\end{array}$ & $\begin{array}{c}0.85 \\
(5.95)\end{array}$ & & \\
\hline $\begin{array}{r}\text { For Lowly versus Highly Capitalized Bank (1 St. Dev. Difference) } \\
\text { - Impact of } 1 \text { pp Decrease in Overnight Rate on Granting to Risky Firms } \\
\text { - Impact of } 1 \text { pp Decrease in Control on Granting to Risky Firms }\end{array}$ & $7.9 \%$ & $2.9 \%$ & $\begin{array}{l}9.2 \% \\
4.0 \%\end{array}$ & $\begin{array}{l}8.5 \% \\
0.7 \%\end{array}$ & $9.2 \%$ & \\
\hline \multicolumn{7}{|l|}{ SECOND STEP } \\
\hline $\begin{array}{l}\left.\text { Dependent Variable: } \mathrm{LN}_{(\mathrm{CREDIT}} \mathrm{AMOUNT}_{t b i}\right) \\
\quad \Delta \text { OVERNIGHT RATE }_{t-1} * I\left(\text { FIRM RISK }_{t i}\right) * \mathrm{LN}\left(\text { BANK CAPITAL }_{t-1 b}\right)\end{array}$ & $\begin{array}{l}82.88^{* * *} \\
(23.18)\end{array}$ & & $\begin{array}{l}86.96^{* * * *} \\
(30.27)\end{array}$ & $\begin{array}{c}55.62^{*} \\
(30.29)\end{array}$ & $\begin{array}{l}86.88^{* *} \\
(41.74)\end{array}$ & $\begin{array}{c}31.39 \\
(28.11)\end{array}$ \\
\hline 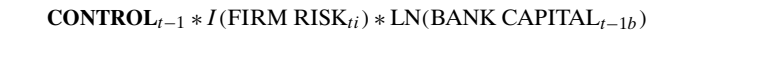 & & $\begin{array}{c}10.08 \\
(29.37)\end{array}$ & $\begin{array}{l}49.10^{* *} \\
(24.11)\end{array}$ & $\begin{array}{c}-15.26 \\
(42.78)\end{array}$ & & \\
\hline $\begin{array}{r}\text { For Lowly versus Highly Capitalized Bank (1 St. Dev. Difference) } \\
\text { - Impact of } 1 \text { pp Decrease in Overnight Rate on Credit to Risky Firms } \\
\text { - Impact of } 1 \text { pp Decrease in Control on Credit to Risky Firms }\end{array}$ & $25.0 \%$ & $3.0 \%$ & $\begin{array}{l}26.2 \% \\
14.8 \%\end{array}$ & $\begin{array}{r}16.8 \% \\
-4.6 \%\end{array}$ & $26.2 \%$ & $9.5 \%$ \\
\hline $\begin{array}{r}\text { For Lowly versus Highly Capitalized Bank (1 St. Dev. Difference) } \\
\text { - Total Impact of } 1 \text { pp Decrease in Overnight Rate on Credit to Risky Firms } \\
\text { - Total Impact of } 1 \text { pp Decrease in Control on Credit to Risky Firms }\end{array}$ & $19.8 \%$ & $5.5 \%$ & $\begin{array}{l}22.3 \% \\
10.6 \%\end{array}$ & $\begin{array}{r}18.5 \% \\
-0.2 \%\end{array}$ & $22.2 \%$ & $13.2 \%$ \\
\hline
\end{tabular}


TABLE III-Continued

\begin{tabular}{|c|c|c|c|c|c|c|}
\hline & (1) & (2) & (3) & (4) & (5) & (6) \\
\hline & 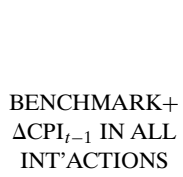 & $\begin{array}{c}\text { BENCHMARK+ } \\
\Delta \text { SPANISH } \\
\text { LONG-TERM } \\
\text { INTEREST } \\
\text { RATE }\end{array}$ & $\begin{array}{c}\text { BENCHMARK+ } \\
\text { AU.S. SHORT } \\
\text { (LONG) } \\
\text { TERM } \\
\text { INTEREST } \\
\text { RATE }\end{array}$ & $\begin{array}{c}\text { BENCHMARK+ } \\
\Delta \text { SPANISH } \\
\text { SECURITIZED } \\
\text { ASSETS/TOT. } \\
\text { ASSETS }\end{array}$ & $\begin{array}{l}\text { TIME*BANK FE+ } \\
\text { CTRLS OF (4) \& } \\
\text { A.III (5) \& (6) }\end{array}$ & $\begin{array}{c}\text { TIME*BANK FE } \\
\text { NO } \\
\text { CORRECTION } \\
\text { FOR SAMPLE } \\
\text { SELECTION: } \\
\text { ONE-STEP }\end{array}$ \\
\hline [(Year-Month)*Firm] Fixed Effects & Yes & Yes & Yes & Yes & Yes & Yes \\
\hline Bank Fixed Effects & Yes & Yes & Yes & Yes & - & - \\
\hline$[($ Year-Month $) *$ Bank] Fixed Effects & No & No & No & No & Yes & Yes \\
\hline Bank Controls & Yes & Yes & Yes & Yes & Yes & - \\
\hline$\left\{\Delta \mathrm{GDP}_{t-1}, \Delta \mathrm{CPI}_{t-1}\right\} * I\left(\mathrm{FIRM} \mathrm{RISK}_{t i}\right) * \mathrm{LN}\left(\mathrm{BANK} \mathrm{CAPITAL}_{t-1 b}\right)$ & Yes & Yes & Yes & Yes & Yes & Yes \\
\hline$\Delta$ OVERNIGHT RATE $_{t-1} * I\left(\right.$ FIRM RISK $\left._{t i}\right) *\left\{\right.$ Bank Controls $\left._{t-1 b}\right\}$ & Yes & Yes & Yes & Yes & Yes & Yes \\
\hline
\end{tabular}

${ }^{a}$ This table reports in models (1)-(5) the estimates from type-2 Tobit sample selection models, which explain the probability that a loan application is approved by a bank and the loan is granted to a firm that is new to the bank (extensive margin of new lending) and the committed amount of granted loans by the bank to a firm given its loan application was successful (intensive margin of new lending). The estimates of the first step in this table come from linear probability models using ordinary least squares and 241,052 observations from the 2002:02-2008:12 period. The estimates of the second step come from the second stage of a two-step estimation procedure for panel data sample selection models outlined by Kyriazidou (1997) using kernel least squares. It uses 38,334 observations. The estimates in model (6) come from a one-step ordinary least squares regression. The dependent variables are $I$ (GRANTING OF LOAN APPLICATIONS $t b i$ ), which equals 1 if the loan application made in month $t$ to bank $b$ by firm $i$ is successful and the loan is granted in $t$ to $t+3$, and equals 0 otherwise; and LN(CREDIT AMOUNT $t b i$ ), which following a successful application filed in month $t$ to bank $b$ by firm $i$ is the logarithm of the committed loan amount granted in $t$ to $t+3$ by bank $b$ to firm $i$. The definition of the independent variables can be found in the Appendix (FIRM RISK is based on a 4-year credit history). Where possible, a constant is included but its coefficient is left unreported. Where possible, all macro, bank, and firm variables in triple interactions are included in levels and in double interactions but their coefficients are left unreported. Fixed effects are either included ("Yes"), not included ("No"), or spanned by another set of effects ("-"). For each variable, the first row lists the coefficient, the second row lists the robust standard error that is corrected for multiclustering at the year-month, bank, and firm level; the corresponding significance levels are adjacent to the coefficient in the second column. The single-stage/total impact is calculated as the percent change in the mean granting probability or times the credit amount following a 1 percentage point decrease in the overnight interest rate or control variable and lending to firms with doubtful loans in the previous four years by a lowly versus highly capitalized bank that differ by 1 standard deviation in capitalization. ${ }^{*} p<0.10 ; * * p<0.05 ;{ }^{* * *} p<0.01$. 


\subsection{Figures}

Before turning to the regression estimates from the two stages, Figures 1 and 2 provide a visual preview of the findings. Representing the first stage, Figure 1 plots, at a yearly and quarterly frequency, (a) the probability a loan application is granted (left-hand scale) by a bank with low versus high capital (by median) to an otherwise average firm with nonperforming loans outstanding in the previous 4 years versus a firm without and (b) the change in the overnight interest rate (right-hand scale). For the second stage, Figure 2 similarly plots the logarithm of the committed amount of granted loans and the change in the overnight interest rate. The plotted variables are demeaned over the year or quarter, respectively (which is similar to controlling for year*firm or quarter*firm fixed effects).

The figures show clearly that when the overnight interest rate decreases, lowly capitalized banks grant more loan applications to risky firms than do highly capitalized banks, and also than to firms without recent nonperforming loans. The same is true for the committing of granted loan amounts. Spanish bank securitization or current account deficit (implying a capital inflow) for example, which are not plotted but are well known to be higher in the latter part of the sample period (and which will also be featured in our regressions), can therefore not be driving bank risk-taking in lending.

\subsection{Main Results}

In Tables II-VI, we analyze the sample that consists of business loan applications with the panel two-stage selection model. Our main Table II analyzes the risk-taking channel of monetary policy, the first stage with the granting of loan applications, and, for the applications granted, the second stage with the logarithm of the committed amount of granted loans. Included are time $*$ firm fixed effects as of model (5) (our benchmark model), and time $*$ bank fixed effects in model (6).

Table III builds further to an exhaustive specification that contains triple interactions with all key macro controls in model (5), while Table IV varies the time horizon of the measure of firm credit risk. Tables V and VI feature second stages with the future likelihood of loan default and collateral requirements as dependent variables. In all cases, we also show estimates from secondstage-like regressions of loan outcomes without accounting for the first stage of granting applications, that is, least squares regressions of the observed loan outcomes.

Model (1) in Table II simply introduces firm risk in level, and models (2) and (3) introduce its interaction with monetary rates in the most general case of no firm fixed effects. ${ }^{23}$ The results suggest that risky firms obtain less credit, both

\footnotetext{
${ }^{23}$ In models (1)-(3), we estimate Equation (1) without the triple interactions and with a large set of firm controls that proxy for firm investment opportunities (industry, location, and profits) and net worth (leverage and size).
} 


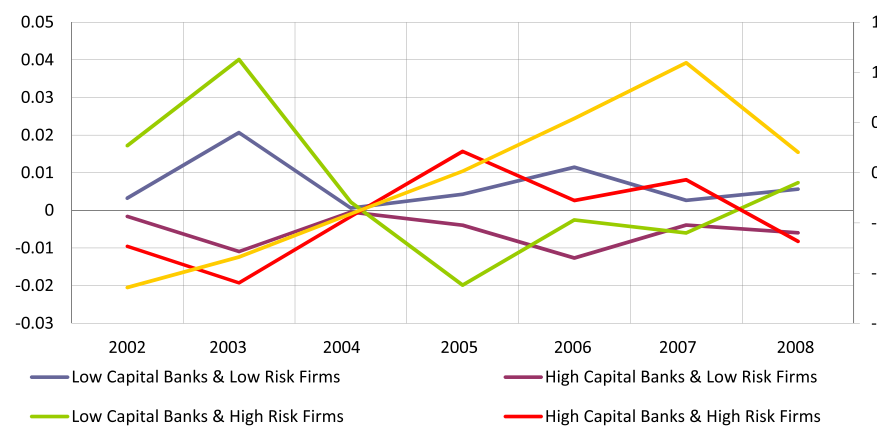

Change in Overnight Interest Rate (Right-Hand Scale)

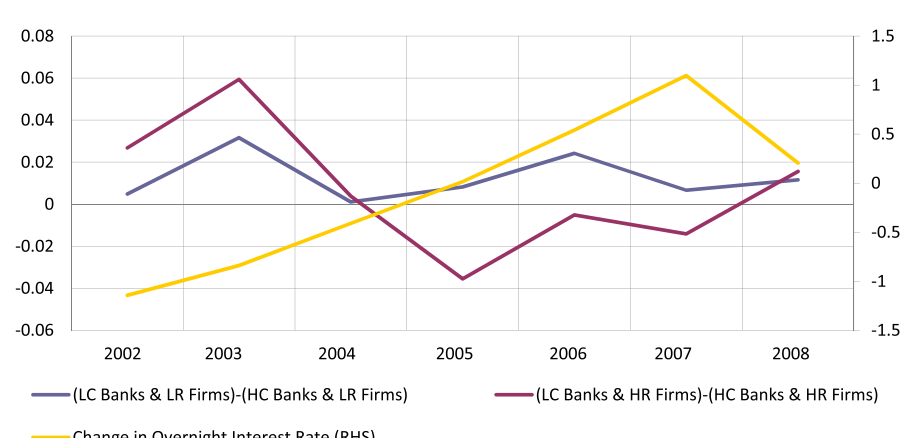

Change in Overnight Interest Rate (RHS)

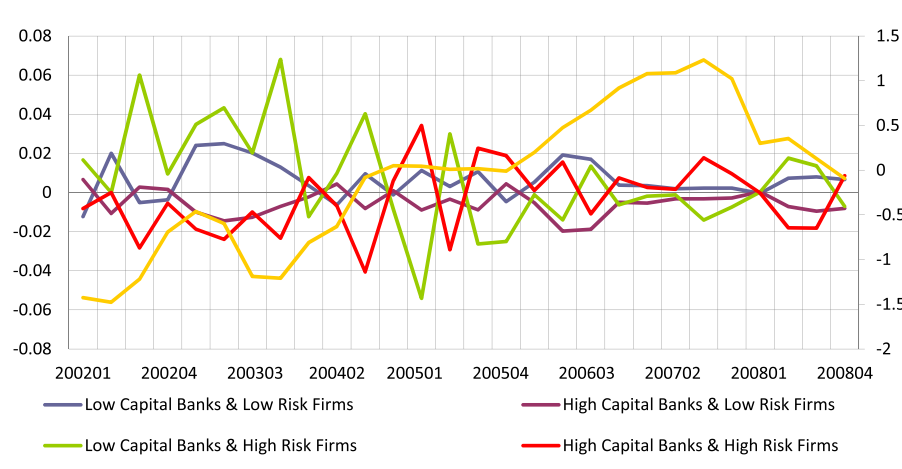

—Change in Overnight Interest Rate (RHS)

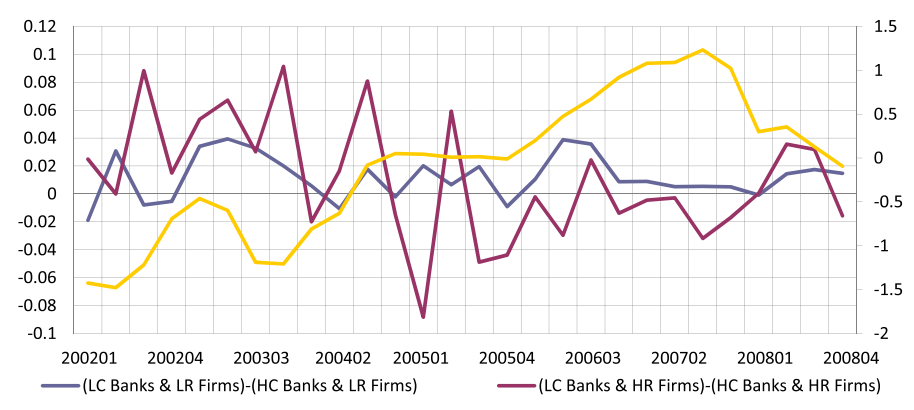

Change in Interest Rate (RHS)

A: Annual frequency

B: Quarterly frequency

FIGURE 1.-The probability a loan application is granted (left-hand scale) by a bank with low versus high capital (by median) to an otherwise average firm with non-performing loans outstanding in the previous 4 years (HR) versus a firm without (LR), and the change in the overnight interest rate (right-hand scale). 

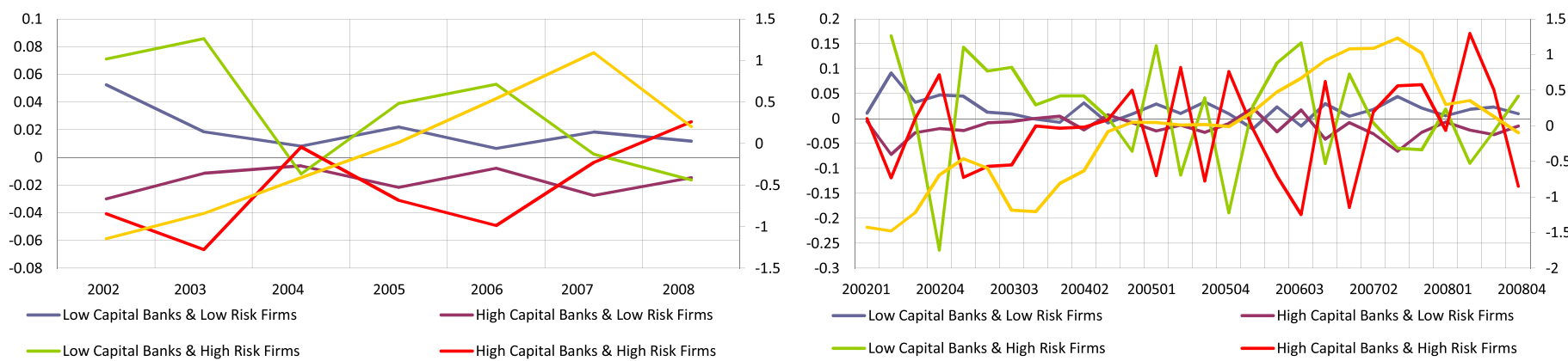

Change in Overnight Interest Rate (Right-Hand Scale)

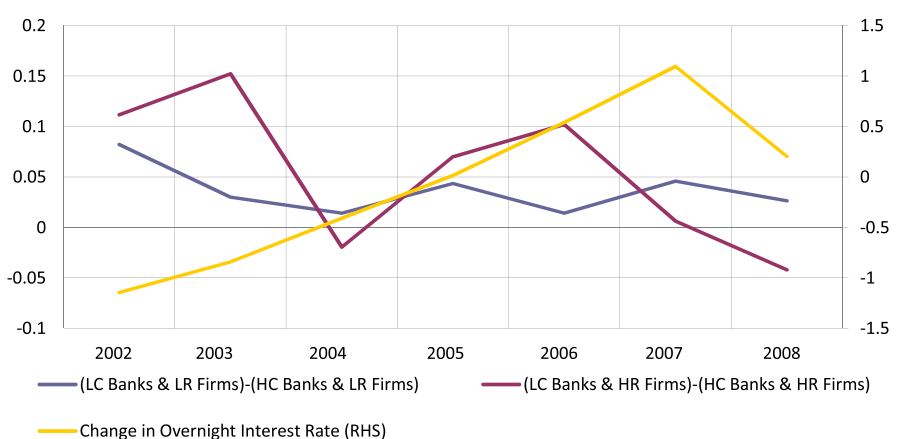

Change in Overnight Interest Rate (RHS)
Change in Overnight Interest Rate (RHS)

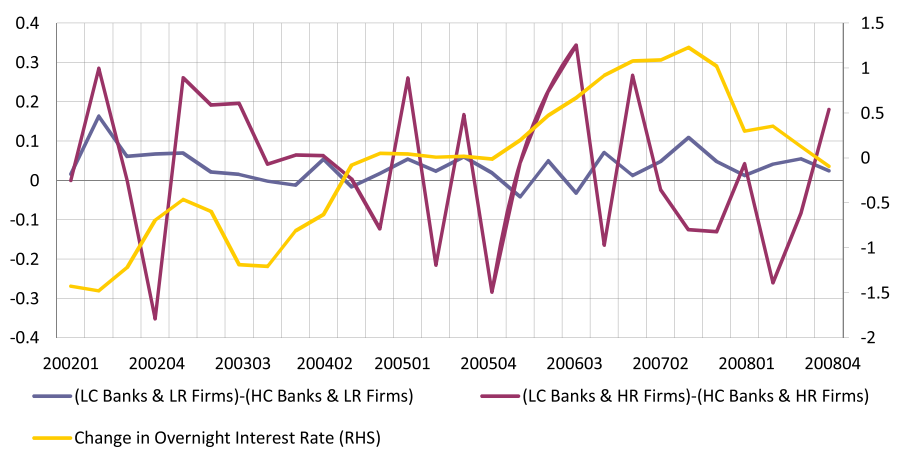

B: Quarterly frequency

FIGURE 2.-The logarithm of the committed amount of granted loans (left-hand scale) by a bank with low versus high capital (by median) to an otherwise average firm with non-performing loans outstanding in the previous 4 years (HR) versus a firm without (LR), and the change in the overnight interest rate (right-hand scale). 
TABLE IV

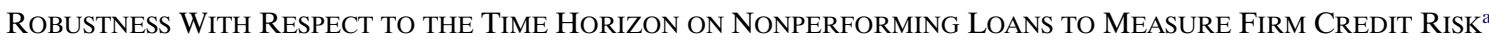

\begin{tabular}{|c|c|c|c|c|c|}
\hline & (1) & (2) & (3) & (4) & (5) \\
\hline FIRM CREDIT RISK Time Horizon: & 5 YEARS & $\begin{array}{l}\text { BENCHMARK: } \\
4 \text { YEARS }\end{array}$ & 3 YEARS & 2 YEARS & 1 YEAR \\
\hline \multicolumn{6}{|l|}{ FIRST STEP } \\
\hline$\Delta$ OVERNIGHT RATE $_{t-1} * I\left(\right.$ FIRM RISK $\left._{t i}\right) *$ LN $\left(\right.$ BANK CAPITAL $\left._{t-1 b}\right)$ & $\begin{array}{r}9.05^{*} \\
(4.87)\end{array}$ & $\begin{array}{l}9.89^{* *} \\
(4.72)\end{array}$ & $\begin{array}{l}10.93^{* *} \\
(5.27)\end{array}$ & $\begin{array}{l}13.49^{* * *} \\
(5.22)\end{array}$ & $\begin{array}{c}8.49 \\
(6.43)\end{array}$ \\
\hline $\begin{array}{r}\text { Impact of } 1 \text { pp Decrease in Overnight Rate on Granting to Risky Firms } \\
\text { by Lowly versus Highly Capitalized Bank (1 St. Dev. Difference) }\end{array}$ & $7.7 \%$ & $8.4 \%$ & $9.2 \%$ & $11.4 \%$ & $7.2 \%$ \\
\hline \multicolumn{6}{|l|}{ SECOND STEP } \\
\hline$\Delta$ OVERNIGHT RATE $_{t-1} * I\left(\right.$ FIRM RISK $\left._{t i}\right) *$ LN $\left(\right.$ BANK CAPITAL $\left._{t-1 b}\right)$ & $\begin{array}{l}58.31^{* * *} \\
(17.91)\end{array}$ & $\begin{array}{l}58.94^{* *} \\
(24.96)\end{array}$ & $\begin{array}{l}45.34^{* *} \\
(22.67)\end{array}$ & $\begin{array}{r}42.95^{*} \\
(22.38)\end{array}$ & $\begin{array}{l}88.02^{* * *} \\
(31.38)\end{array}$ \\
\hline $\begin{array}{l}\text { Impact of } 1 \text { pp Decrease in Overnight Rate on Credit to Risky Firms } \\
\text { by Lowly versus Highly Capitalized Bank (1 St. Dev. Difference) }\end{array}$ & $17.6 \%$ & $17.8 \%$ & $13.7 \%$ & $12.9 \%$ & $26.5 \%$ \\
\hline $\begin{array}{r}\text { Total Impact of } 1 \text { pp Decrease in Overnight Rate on Credit to Risky Firms } \\
\text { by Lowly versus Highly Capitalized Bank (1 St. Dev. Difference) }\end{array}$ & $17.3 \%$ & $18.5 \%$ & $18.8 \%$ & $22.0 \%$ & $7.6 \%$ \\
\hline
\end{tabular}


TABLE IV—Continued

\begin{tabular}{|c|c|c|c|c|c|}
\hline \multirow[b]{2}{*}{ FIRM CREDIT RISK Time Horizon: } & $(1)$ & \multirow{2}{*}{$\begin{array}{c}\frac{(2)}{\text { BENCHMARK: }} \\
4 \text { YEARS }\end{array}$} & \multirow{2}{*}{$\frac{(3)}{3 \text { YEARS }}$} & \multirow{2}{*}{$\frac{(4)}{2 \text { YEARS }}$} & \multirow{2}{*}{$\frac{(5)}{1 \text { YEAR }}$} \\
\hline & 5 YEARS & & & & \\
\hline [(Year-Month)*Firm] Fixed Effects & Yes & Yes & Yes & Yes & Yes \\
\hline Bank Fixed Effects & Yes & Yes & Yes & Yes & Yes \\
\hline Bank Controls & Yes & Yes & Yes & Yes & Yes \\
\hline$\left\{\Delta \mathrm{GDP}_{t-1}, \Delta \mathrm{CPI}_{t-1}\right\} * I\left(\mathrm{FIRM} \mathrm{RISK}_{t i}\right) * \mathrm{LN}\left(\right.$ BANK CAPITAL $\left._{t-1 b}\right)$ & Yes & Yes & Yes & Yes & Yes \\
\hline$\Delta$ OVERNIGHT RATE $_{t-1} * I\left(\right.$ FIRM RISK $\left._{t i}\right) *\left\{\right.$ Bank Controls $\left._{t-1 b}\right\}$ & Yes & Yes & Yes & Yes & Yes \\
\hline $\begin{array}{l}\text { aThis table reports estimates from type-2 Tobit sample selection models, which } \\
\text { to a firm that is new to the bank (extensive margin of new lending) and the commi } \\
\text { (intensive margin of new lending). The estimates of the first step in this table come } \\
\text { the 2002:02-2008:12 period. The estimates of the second step come from the secon } \\
\text { by Kyriazidou (1997) using kernel least squares. It uses } 38,334 \text { observations. The de } \\
\text { loan application made in month } t \text { to bank } b \text { by firm } i \text { is successful and the loan is gra } \\
\text { successful application filed in month } t \text { to bank } b \text { by firm } i \text { is the logarithm of the comr } \\
\text { variables can be found in the Appendix (FIRM RISK is based on a 4-year credit } \\
\text { possible, all macro, bank, and firm variables in triple interactions are included in leve } \\
\text { included ("Yes"), not included ("No"), or spanned by another set of effects ("-")."). } \\
\text { error that is corrected for multiclustering at the year-month, bank, and firm level; th } \\
\text { single-stage/total impact is calculated as the percent change in the mean granting pr } \\
\text { interest rate and lending to firms with doubtful loans in the previous } 4 \text { years by a lowly } \\
* * p<0.05 ; * * * p<0.01 \text {. }\end{array}$ & $\begin{array}{l}\mathrm{n} \text { the proba } \\
\text { mount of gr } \\
\text { linear prob } \\
\text { of a two-s } \\
\text { ent variables } \\
\text { n } t \text { to } t+3 \text {, } \\
\text { loan amour } \\
\text { ). Where p } \\
\text { in double ir } \\
\text { ach variable } \\
\text { lity or times } \\
\text { us highly cap }\end{array}$ & $\begin{array}{l}\text { that a loan applica } \\
\text { loans by the bank } \\
\text { y models using ord } \\
\text { stimation procedur } \\
\text { (GRANTING OF } \\
\text { quals } 0 \text { otherwise; a } \\
\text { nted in } t \text { to } t+3 \text { by } \\
\text {, a constant is inc } \\
\text { tions but their coef } \\
\text { first row lists the cc } \\
\text { cance levels are ad } \\
\text { edit amount follow } \\
\text { ed bank that differ }\end{array}$ & $\begin{array}{l}\text { least square } \\
\text { panel data s } \\
\text { N APPLICA } \\
\text { N(CREDIT } \\
b \text { to firm } i \text {. } \\
\text { but its coef } \\
\text { ts are left un } \\
\text { ient, the seco } \\
t \text { to the coef } \\
1 \text { percentag } \\
\text { tandard devi }\end{array}$ & $\begin{array}{l}241,052 \mathrm{ob} \\
\text { e selection } \mathrm{r} \\
\mathrm{NS}_{t b i} \text {, which } \\
\mathrm{UNT}_{t b i} \text {, w } \\
\text { efinition of } \mathrm{t} \\
\text { it is left unr } \\
\text { rted. Fixed e } \\
\text { ow lists the } \\
\mathrm{t} \text { in the seco } \\
\text { nt decrease } \\
\text { in capitaliza }\end{array}$ & $\begin{array}{l}\text { is granted } \\
\text { successful } \\
\text { tions from } \\
\text { ls outlined } \\
\text { als } 1 \text { if the } \\
\text { ollowing a } \\
\text { dependent } \\
\text { d. Where } \\
\text { are either } \\
\text { t standard } \\
\text { lumn. The } \\
\text { overnight } \\
* p<0.10 \text {; }\end{array}$ \\
\hline
\end{tabular}


TABLE V

The Probability That a Firm Becomes Delinguent With the BANK IN THE FuturE ${ }^{\mathrm{a}}$

\begin{tabular}{|c|c|c|c|c|c|c|}
\hline & (1) & (2) & (3) & (4) & (5) & $\begin{array}{c}\text { (6) } \\
\text { ONE-STEP }\end{array}$ \\
\hline \multicolumn{7}{|l|}{ FIRST STEP } \\
\hline \multicolumn{7}{|l|}{ Dependent Variable: I (GRANTING OF LOAN APPLICATIONS $\left.{ }_{t b i}\right)$} \\
\hline$\Delta$ OVERNIGHT RATE ${ }_{t-1}$ & $\begin{array}{c}-2.04 \\
(4.58)\end{array}$ & $\begin{array}{c}-6.31 \\
(4.59)\end{array}$ & & & & \\
\hline LN(BANK CAPITAL $\left.{ }_{t-1 b}\right)$ & $\begin{array}{c}-0.02 \\
(0.04)\end{array}$ & $\begin{array}{c}0.05 \\
(0.05)\end{array}$ & $\begin{array}{c}0.05 \\
(0.05)\end{array}$ & $\begin{array}{c}0.06 \\
(0.06)\end{array}$ & $\begin{array}{l}0.28^{* * *} \\
(0.08)\end{array}$ & \\
\hline$\Delta$ OVERNIGHT RATE $_{t-1} *$ LN $\left(\right.$ BANK CAPITAL $\left._{t-1 b}\right)$ & $\begin{array}{r}2.09^{*} \\
(1.22)\end{array}$ & $\begin{array}{c}0.81 \\
(1.37)\end{array}$ & $\begin{array}{c}0.84 \\
(1.34)\end{array}$ & $\begin{array}{c}0.58 \\
(1.54)\end{array}$ & $\begin{array}{c}0.10 \\
(1.51)\end{array}$ & \\
\hline \multicolumn{7}{|l|}{ SECOND STEP } \\
\hline $\begin{array}{l}\text { Dependent Variable: } I(\mathrm{FUTURE} \text { DEFAULT } \\
t b i \\
\Delta \text { OVERNIGHT RATE }_{t-1}\end{array}$ & $\begin{array}{r}-16.37^{*} \\
(9.93)\end{array}$ & $\begin{array}{c}-37.63^{* * *} \\
(8.89)\end{array}$ & & & & \\
\hline LN(BANK CAPITAL $\left.{ }_{t-1 b}\right)$ & $\begin{array}{c}-0.11 \\
(0.08)\end{array}$ & $\begin{array}{c}-0.02 \\
(0.11)\end{array}$ & $\begin{array}{c}-0.02 \\
(0.11)\end{array}$ & $\begin{array}{c}-0.05 \\
(0.12)\end{array}$ & $\begin{array}{c}-0.14 \\
(0.19)\end{array}$ & $\begin{array}{c}2.70 \\
(1.70)\end{array}$ \\
\hline$\Delta$ OVERNIGHT RATE $_{t-1} *$ LN $\left(\right.$ BANK CAPITAL $\left._{t-1 b}\right)$ & $\begin{array}{r}3.77^{*} \\
(2.26)\end{array}$ & $\begin{array}{l}3.93^{* *} \\
(1.99)\end{array}$ & $\begin{array}{r}3.59^{*} \\
(2.12)\end{array}$ & $\begin{array}{l}6.17^{* * *} \\
(2.39)\end{array}$ & $\begin{array}{l}6.27^{* * *} \\
(2.42)\end{array}$ & $\begin{aligned} 3.20^{*} \\
(1.84)\end{aligned}$ \\
\hline $\begin{array}{l}\text { Impact of } 1 \text { pp Decrease in Overnight Rate on Future Default } \\
\text { by Lowly versus Highly Capitalized Bank (1 St. Dev. Difference) }\end{array}$ & $3.2 \%$ & $3.3 \%$ & $3.1 \%$ & $5.3 \%$ & $5.3 \%$ & $2.7 \%$ \\
\hline $\begin{array}{l}\text { Total Impact of } 1 \text { pp Decrease in Overnight Rate on Future Default } \\
\quad \text { by Lowly versus Highly Capitalized Bank (1 St. Dev. Difference) }\end{array}$ & $2.6 \%$ & $1.0 \%$ & $0.9 \%$ & $1.5 \%$ & $1.5 \%$ & $0.8 \%$ \\
\hline
\end{tabular}


TABLE V—Continued

$\begin{array}{llllllll}(1) & (2) \quad(3) \quad(4) \quad(5) \quad(6)\end{array}$

\begin{tabular}{|c|c|c|c|c|c|c|}
\hline (Year-Month) Fixed Effects & No & No & Yes & - & - & - \\
\hline Firm Fixed Effects & Yes & Yes & Yes & - & - & - \\
\hline Bank Fixed Effects & No & Yes & Yes & Yes & Yes & Yes \\
\hline$[($ Year-Month $) *$ Firm] Fixed Effects & No & No & No & Yes & Yes & Yes \\
\hline PERIOD IN WHICH FIRM CAN DEFAULT and PERIOD SQUARED & Yes & Yes & - & - & - & - \\
\hline Bank Controls & Yes & Yes & Yes & Yes & Yes & Yes \\
\hline$\left\{\Delta \mathrm{GDP}_{t-1}, \Delta \mathrm{CPI}_{t-1}\right\} * \mathrm{LN}\left(\mathrm{BANK} \mathrm{CAPITAL}_{t-1 b}\right)$ & Yes & Yes & Yes & Yes & Yes & Yes \\
\hline$\left\{\Delta\right.$ U.S. Short-Term IR $t_{t-1}, \Delta$ Securit. $/ \mathrm{TA}_{t-1}, \Delta$ Curr. Acc./GDP $\left.{ }_{t-1}\right\} * \mathrm{LN}\left(\mathrm{BANK} \mathrm{CAPITAL}_{t-1 b}\right)$ & No & No & No & No & Yes & No \\
\hline$\Delta$ OVERNIGHT RATE $_{t-1} *\{$ Bank Controls $\}$ & Yes & Yes & Yes & Yes & Yes & Yes \\
\hline
\end{tabular}

${ }^{a}$ This table reports in models (1)-(5) the estimates from type-2 Tobit sample selection models, which explain the probability that a loan application is approved by a bank and the loan is granted to a firm that is new to the bank (extensive margin of new lending) and subsequently the firm defaults (risk-taking margin of new lending). The estimates of the first step in this table come from linear probability models using ordinary least squares and 241,052 observations from the 2002:02-2008:12 period. The estimates of the second step come from the second stage of a two-step estimation procedure for panel data sample selection models outlined by Kyriazidou (1997) using kernel least squares. It uses 38,334 observations. The estimates in model (6) come from a one-step ordinary least squares regression. The dependent variables are $I$ (GRANTING OF LOAN APPLICATIONS $t b i$ ), which equals 1 if the loan application made in month $t$ to bank $b$ by firm $i$ is successful and the loan is granted in $t$ to $t+3$, and equals 0 otherwise; and $I$ (FUTURE DEFAULT $t b i$ ), which equals 1 when firm $i$ that is granted the loan at time $t$ by bank $b$ defaults at some point in the future. The definition of the independent variables can be found in the Appendix (FIRM RISK is based on a 4-year credit history). Where possible, a constant is included but its coefficient is left unreported. Where possible, all macro and bank level variables in double interactions and the double interactions reported in the table are included in levels but their coefficients are left unreported. Fixed effects are either included ("Yes"), not included ("No"), or spanned by another set of effects ("--). For each variable the first row lists the coefficient, the second row lists the robust standard error that is corrected for multiclustering at the year-month, bank, and firm level; the corresponding significance levels are adjacent to the coefficient in the second column. The single-stage (total) impact is calculated as the percent change in the mean default probability (times the probability a loan application is granted) following on a 1 percentage point decrease in the overnight interest rate for a lowly versus highly capitalized bank that differ by 1 standard deviation in capitalization. ${ }^{*} p<0.10 ;{ }^{* *} p<0.05 ;{ }^{* * *} p<0.01$. 
TABLE VI

LOANS GRANTED WITHOUT COLLATERAL ${ }^{\mathrm{a}}$

\begin{tabular}{|c|c|c|c|}
\hline & (1) & (2) & (3) \\
\hline & $\begin{array}{c}\text { Table II } \\
\text { Model (5) }\end{array}$ & $\begin{array}{c}\text { Table III } \\
\text { Model (5) }\end{array}$ & $\begin{array}{c}\text { Table III } \\
\text { Model (6) } \\
\text { ONE-STEP }\end{array}$ \\
\hline \multicolumn{4}{|l|}{ FIRST STEP } \\
\hline \multicolumn{4}{|l|}{ Dependent Variable: $I\left(\right.$ GRANTING OF LOAN APPLICATIONS $\left._{t b i}\right)$} \\
\hline$\Delta$ OVERNIGHT RATE $_{t-1} * I\left(\right.$ FIRM RISK $\left._{t i}\right) *$ LN $\left(\right.$ BANK CAPITAL $\left._{t-1 b}\right)$ & $\begin{array}{c}9.89^{* *} \\
(4.72)\end{array}$ & $\begin{array}{l}10.82^{*} \\
(5.75)\end{array}$ & \\
\hline $\begin{array}{r}\text { Impact of } 1 \text { pp Decrease in Overnight Rate on Uncollateralized Credit to Risky Firms } \\
\text { by Lowly versus Highly Capitalized Bank (1 St. Dev. Difference) }\end{array}$ & $8.4 \%$ & $9.2 \%$ & \\
\hline \multicolumn{4}{|l|}{ SECOND STEP } \\
\hline \multicolumn{4}{|l|}{ Dependent Variable: $I\left(\right.$ WITHOUT COLLATERAL $\left._{t b i}\right)$} \\
\hline$\Delta$ OVERNIGHT RATE $_{t-1} * I\left(\right.$ FIRM RISK $\left._{t i}\right) *$ LN $\left(\right.$ BANK CAPITAL $\left._{t-1 b}\right)$ & $\begin{array}{c}7.94 \\
(9.80)\end{array}$ & $\begin{aligned} 19.60^{*} \\
(11.69)\end{aligned}$ & $\begin{array}{l}12.25 \\
(9.77)\end{array}$ \\
\hline $\begin{array}{r}\text { Impact of } 1 \text { pp Decrease in Overnight Rate on Uncollateralized Credit to Risky Firms } \\
\text { by Lowly versus Highly Capitalized Bank (1 St. Dev. Difference) }\end{array}$ & $2.7 \%$ & $6.6 \%$ & $4.1 \%$ \\
\hline $\begin{array}{r}\text { Total Impact of } 1 \text { pp Decrease in Overnight Rate on Uncollateralized Credit to Risky Firms } \\
\text { by Lowly versus Highly Capitalized Bank (1 St. Dev. Difference) }\end{array}$ & $3.5 \%$ & $4.8 \%$ & $4.1 \%$ \\
\hline
\end{tabular}


TABLE VI-Continued

\begin{tabular}{l}
\hline \hline \\
Bank Fixed Effects \\
[(Year-Month)*Firm] Fixed Effects \\
[(Year-Month)*Bank] Fixed Effects \\
$\Delta \mathrm{OVERNIGHT} \mathrm{RATE}$ F $_{t-1} * I$ (FIRM RISK $\left.{ }_{t i}\right) *\left\{\right.$ Bank Controls $\left.{ }_{t-1 b}\right\}$
\end{tabular}

bank (that differ by one standard deviation in capitalization). ${ }^{*} p<0.10 ;{ }^{* *} p<0.05 ;{ }^{* * *} p<0.01$. 
their applications are less likely to be granted, and, if granted, banks commit lower credit amounts ( $\hat{\beta}$ and $\hat{\beta}^{\prime}$ are negative). In addition, when the overnight interest rate decreases, banks grant and commit more credit to all firms, ${ }^{24}$ but especially to risky firms, that is, the estimated coefficients $\hat{\delta}$ and $\hat{\delta}^{\prime}$ on the double $\Delta$ OVERNIGHT RATE $t-1 * I\left(\right.$ FIRM RISK $\left._{t i}\right)$ in both stages are negative and statistically significant.

Table II also contains an assessment of the economic relevancy of the coefficients given in italics below the estimates for each stage. A 1 percentage point decrease in the overnight interest rate in model (3), which includes bank fixed effects, increases the granting of loan applications to risky firms (i.e., with nonperforming loans in the previous 4 years) for the mean bank by 7 percent (at the mean of the dependent variable, which equals 36 percent) and the credit amount committed by 26 percent. These changes amount to a total change in the probability that a loan application is granted times the credit amount committed that equals 19 percent. ${ }^{25}$ Moreover, if we analyze only within-firm variation, the extensive margin result (not surprisingly) disappears, but the intensive margin result becomes stronger in economic terms. These results hold for both average bank capital (see model (4) of Table II) and for high or low bank capital (see models (1) and (2) of Table A.IV in the Supplemental Material). ${ }^{26}$

The results always imply that when monetary rates are lower, banks grant more credit to riskier firms. If we analyze only within-firm variation, the extensive margin is not statistically significant and the effect is entirely through the credit volume granted (intensive margin). If we do not restrict the analysis to within-firm variation (and hence analyze the macro effect), then the effects arise at both the extensive (more granting of applications) and intensive (more credit volume) margins.

As explained earlier (in the Introduction and in the empirical strategy), the identification of the supply of credit requires having time $*$ firm fixed effects in loan application models: the double interaction of firm risk and the overnight rate can capture changes in the composition of credit but not in the composition of the supply of credit. Therefore, only the triple interaction of firm risk, the overnight rate, and bank capital identifies bank risk-taking.

\footnotetext{
${ }^{24}$ In unreported specifications without time fixed effects (which account for all observed and unobserved variation in the macro environment), we find that the estimated coefficient on the overnight interest rate is consistently negative.

${ }^{25}$ The total change in credit amount can be larger than zero, even if the probability that a loan application is granted is not affected (because the total change equals the change on the extensive margin times the intensive margin plus the extensive margin times the change on the intensive margin).

${ }^{26}$ When there are double and triple interactions, the data are demeaned; therefore, the doubles are evaluated at the sample mean, which gives these estimates an immediate economic interpretation. Therefore, the estimates of the doubles of model (4) without the triples are very similar (1.91 for the first stage and $-55.8^{*}$ for the second stage).
} 
In models (4), (5), and (6) we analyze these triple interactions. Model (4) in Table II estimates the specification we introduced earlier in Equation (1), model (5) is identical to model (4), but we replace firm fixed effects with firm $*$ time fixed effects to identify credit supply and risk-taking, and model (6) adds time $*$ bank fixed effects to the time $*$ firm fixed effects (i.e., it estimates Equation (2)).

We find in model (4) that the risk-taking effect of a lower monetary rate is strengthened for lowly capitalized banks, that is, in both stages the estimated coefficients, $\hat{\gamma}$ and $\hat{\gamma}^{\prime}$, on the triple of overnight rate, bank capital, and firm risk are positive and statistically significant (we assess economic relevancy in the next subsection). A positive coefficient on this "triple" (interaction) importantly implies that when the overnight rate declines, lowly capitalized banks grant more applications and larger loan amounts to risky firms, that is, these banks take more risk.

Model (5) adds time $*$ firm fixed effects to assess the differences in the granting and committing of credit following changes in the overnight interest rate in the same month by banks of different capital ratios to the same firm. ${ }^{27}$ $\hat{\gamma}$ and $\hat{\gamma}^{\prime}$ remain positive and statistically significant. The coefficient actually increases in size in the first stage, thus suggesting a nonrandom matching and the importance of controlling well for firm quality (with firm *time fixed effects). Model (5) is our benchmark regression with firm*time fixed effects, bank fixed effects, triples (of the overnight rate and firm risk) with the bank controls. $^{28}$

Model (6) adds time $*$ bank fixed effects to the time $*$ firm fixed effects, bank controls, the two parallel triples with GDP and inflation, and the six parallel triples with bank controls. The coefficient of the triple interaction of interest remains positive and marginally significant in both stages. Despite the near saturation with fixed effects and parallel triples, $\hat{\gamma}$ and $\hat{\gamma}^{\prime}$ remain largely unaffected in absolute value, though statistically approaching "suffocation." 29

\footnotetext{
${ }^{27}$ Time $*$ firm effects also control for bank capital and/or the credit granted by the current (existing relationship) banks, as these variables vary at the time-firm ( $t i$ level when the firm applies for financing from new banks $(t b i)$.

${ }^{28}$ The estimated coefficients of the bank triples (e.g., bank size) in both stages are not statistically significant.

${ }^{29}$ There is evidence in the literature that suggests a correlation between the monetary policy rate and risk-taking. Adrian and Shin (2011), in their discussion of the risk-taking channel of monetary policy, documented correlations between short-term interest rates and bank risktaking (see also De Nicolò, Dell'Ariccia, Laeven, and Valencia (2010)). Den Haan, Sumner, and Yamashiro (2007) suggested that high short-term rates could imply a decline in bank risk-taking with U.S. data, and Maddaloni and Peydró (2011) with Euro area data. Gertler and Gilchrist (1994) showed that contractionary monetary policy results in less bank lending to small firms, findings that are consistent not only with the firm balance-sheet channel, but also with possibly less bank risk-taking. In a different setting, Bernanke and Kuttner (2005) found that higher interest rates reduce equity prices, interpreting that tight money may reduce the willingness of stock
} 


\subsection{Further Economic Relevancy and Robustness}

The assessment of the economic relevancy of the estimated triple coefficients in models (5) and (6) is done on the basis of a comparison of the differential impact for lowly versus highly capitalized banks that differ by 1 standard deviation in capitalization, again following a 1 percentage point decrease in the overnight interest rate and for lending to risky firms (i.e., with nonperforming loans in the previous 4 years). The granting of loan applications by lowly capitalized banks to risky firms in model (5) increases by 3 percentage points more (than by highly capitalized banks), implying a change at its mean of 8 percent, while the committing of credit amounts increases by 18 percent! In model (6), the corresponding changes equal 8 and 16 percent, respectively. These percentages suggest the economic importance of monetary policy for bank risk-taking.

In Table II, triples of bank capital and firm risk with Spanish GDP growth and inflation, respectively, horserace with the triples of the overnight rate. Table III enters into the race other macro variables that are correlated with the overnight rate and that could also cause more bank risk-taking. Specifically, Table III assesses the statistical significance and economic relevancy of the impact on risk-taking of the changes in the Spanish 10-year government bond rate, bank securitization, and current account deficit, and the U.S. 10-year government bond and federal funds rate.

The rest of Table III actually shows these estimates to be mostly conservative. Model (1) enters triples of inflation and firm risk with each of the bank controls, that is, size, liquidity, profitability, nonperforming loan ratio, and type. Consequently, the overnight rate and inflation race one-for-one in all possible terms. The economic effect in the second stage jumps to 25 percent, suggesting that the impact of the overnight interest rate once inflation is fully accounted for is even more important for risk-taking.

Next, we put the change in the Spanish 10-year government bond rate, including the now well known triple with bank capital and firm risk, running it by itself (i.e., without the triple of overnight rate) in model (2) in Table III (and horseracing it with the triple of the overnight rate in model (3) in Table A.II in the Supplemental Material). The estimated coefficients on the triple of this long-term interest rate are never statistically significant (while in the horserace, the triple of the overnight rate remains significant and relevant). Estimates therefore strongly suggest it is the change in the short-term rather than the long-term interest rate that matters for bank risktaking.

investors to bear risk (see also Rigobon and Sack (2004) and Bekaert, Hoerova, and Lo Duca (2010)). Expansionary monetary policy and credit risk-taking followed by restrictive monetary policy possibly led to the financial crisis during the 1990s in Japan (Allen and Gale (2004)), while lower real interest rates preceded banking crises in 47 countries (von Hagen and Ho (2007)). 
United States long- and short-term interest rates, that is, the 10-year government bond rate and the federal funds rate, enter jointly in triples (and corresponding nonreported doubles) with bank capital and firm risk in model (3) in Table III (and individually in models (4) and (5) in Table A.III in the Supplemental Material). The estimated coefficients on the changes in the U.S. long-term interest rate are never statistically significant (to conserve space, we tabulate only the coefficients on the funds rate in (3)); those on the U.S. short-term rate are significant at the 10 percent level in the first stage and at the 5 percent level in the second stage. The latter estimates always have the same sign as the estimated coefficients on the (EONIA) overnight rate, that are however statistically significant at the 5 and 1 percent levels, respectively, and double in size (though the standard deviation over the sample period on the federal funds rate equals 1.78 , while on the overnight rate it only equals 0.71). Thus the U.S. short-term interest rate also plays an important role in credit risk-taking.

Model (4) in Table III enters Spanish bank securitization over total assets in the usual way, in triple (and double). The estimated coefficient on the triple in both stages is insignificant. In Table A.III in the Supplemental Material, we add the current account deficit over GDP. A higher current account deficit results in more committing of credit by lowly versus highly capitalized banks to risky firms, but not in more granting of applications. Importantly, in both models, the estimated coefficients on the triple with the overnight rate remain statistically significant and economically relevant.

Finally, model (5) in Table III races all aggregate variables with recurring statistical significance in interactions, that is, the federal funds rate, securitization, the current account deficit, GDP, and inflation, in addition to bank controls, on the "most accidented track" we have featured so far, comprising time $*$ firm and time $*$ bank fixed effects (benchmark model results are similar). While the estimates of the coefficients on the triple interactions with the funds rate and the current account are no longer statistically significant, the overnight rate retains statistical significance and economic relevancy.

In sum, Table III (and Table A.III in the Supplemental Material) shows the strength of the impact of the changes in the monetary policy rate on bank risk-taking in specifications with changes in aggregate output and prices, the 10-year Spanish government bond rate, the U.S. 10-year government bond, the federal funds rate, Spanish bank securitization, and the current account deficit. A lower federal funds rate and higher current account deficits also result in more bank risk-taking. However, the (EONIA) overnight rate is the only key macro variable that has an impact on bank risk-taking that is robustly statistically significant and also economically relevant.

As all the literature on the credit channel analyzes granted loans without loan applications (i.e., they do not analyze nongranted loan applications), we want to understand the direction and magnitude of a possible bias of not controlling for the sample selection bias of the granting of loan applications. The 
last column in Table III (and in Table A.III in the Supplemental Material) presents estimates of the strongest specifications in Table II (that were the last two columns) without actually estimating their first stage, that is, without correcting for the sample selection. As risk-taking already takes place in the granting of loan applications, the correlation between the errors in the first and second stages should be positive. Not correcting for the sample selection indeed reduces the potency of the risk-taking channel of monetary policy, that is, the economic effect drops from 16 to 9 percent and from 18 to 13 percent, respectively. ${ }^{30}$

These findings raise the possibility of a bias in the extant empirical literature that estimates the potency of the credit channel. With loan applications and time*firm fixed effects, not only can we directly account for the effects from the firm balance-sheet and demand channels, but, crucially, with the firststage model, we can account for the risk-shifting in loan application granting that could otherwise bias any analysis of loan outcomes for the applications granted. Therefore, our results suggest that an econometric analysis can be substantially biased if it is based only on granted loan data, either at the macro- or bank-level data (as in Bernanke and Blinder (1992) and Kashyap and Stein (2000), for example), or at the (only granted) loan-level data without loan application information (as in Khwaja and Mian (2008), for example). ${ }^{31}$

Table IV further shows the robustness of the estimates to changes in the time period over which firm credit risk is being assessed, that is, from 5 to 1 year prior to the loan application. The estimates of the coefficients on the

\footnotetext{
${ }^{30}$ If there is a risk-taking channel of monetary policy, one would expect it to exist both for the granting of loan applications (first stage) and for the change in loan volume (second stage). This is what we find. Notice, however, that a risk-taking channel implies that if, for example, the monetary rate is higher, the granting of loan applications by lowly capitalized banks to risky firms will decrease. Consequently, there will be a bias in the main coefficient estimated in the second stage if this sample selection in application granting is not adequately accounted for, because the ("based-on-observables") risky firms that are granted a loan under such circumstances (i.e., for a higher monetary rate and from a lowly capitalized bank) must have some unobserved good credit quality that allows them to obtain a loan anyway in those difficult circumstances! And this good unobserved quality will also make these firms able to obtain more credit in the second stage, in this way biasing downwards the estimated (reduction in) risk-taking. Put differently, there is a positive correlation between the errors in the first- and second-stage regressions. Estimation à la Wooldridge (1995) yields similar results (see Table A.II in the Supplemental Material).

${ }^{31}$ The estimates for the extended sample covering the 1988:II-2008:IV period suggest that a decrease in the overnight rate leads lowly capitalized banks to increase lending to risky firms more than highly capitalized banks (see Tables A.I and A.V in the Supplemental Material). Results are robust to controlling for time $*$ firm, and time $*$ bank fixed effects; triples of GDP growth or inflation, bank capital, and firm risk; triples of the overnight rate and firm risk with each one of the bank controls, that is, size, liquidity, profitability, nonperforming loan ratio, and type; all corresponding doubles and variables in levels; and controls at the bank-firm level, that is, the one-quarter lag of the dependent variable (as a time-varying bank-firm level control) and a comprehensive set of bank*firm fixed effects as time-invariant controls.
} 
triple interaction with the overnight rate in the benchmark model are stable in sign, statistical significance, and economic relevancy (the impact in the first stage varies between 7 and 11 percent; in the second stage between 14 and 27 percent).

\subsection{Future Credit Defaults and Lack of Collateral Requirements}

In Tables V and VI, we study how the changes in monetary policy affect the likelihood of future (i.e., ex post) loan default and the stringency of collateral requirements. ${ }^{32}$ It has been shown that when the overnight rate decreases, lowly capitalized banks supply more credit to ex ante risky firms. Now we analyze whether lowly capitalized banks are also more likely to grant loans to firms that default more ex post or grant more loans without collateral requirements, that is, both loan outcomes are featured as complementary measures of bank risk-taking.

We again employ a selection model, with, in the first stage, the granting of loan applications, and, in the second stage, the use of Tables V and VI as dependent variables: $I$ (FUTURE DEFAULT WITH THE BANK $_{t b i}$ ), a dummy variable that equals 1 when firm $i$ that is granted the loan at time $t$ by bank $b$ defaults at some point in the future to bank $b$, and $I$ (LOAN GRANTED WITHOUT COLLATERAL ${ }_{t b i}$ ), a dummy variable that equals 1 if the loan granted in month $t$ by bank $b$ by firm $i$ is uncollateralized and equals 0 otherwise.

Table $\mathrm{V}$ documents that a decrease in the overnight rate leads especially lowly capitalized banks to grant more loan applications with a higher future likelihood of default: the double interaction of the change in the overnight rate and bank capital in the second stage is positive and statistically significant in all models (1)-(5), and, for example, is robust to the inclusion of firm, bank, and time fixed effects in model (3), and time $*$ firm fixed effects in models (4) and (5). The coefficient on the overnight rate is negative and statistically significant at the 1 percent level in models (1) and (2), that is, with bank and firm fixed effects (because the overnight rate is included, time fixed effects cannot be featured; yet, two time-related variables that are measured in the number of months, that is, the PERIOD IN WHICH FIRM CAN DEFAULT and the PERIOD SQUARED, are included).

Model (5) is further padded with doubles of bank capital with changes in aggregate output and prices, the U.S. federal funds rate, Spanish securitization and current account deficit, bank fixed effects and (time-varying) bank controls, and doubles of the overnight rate with bank controls. In this demanding specification, a 1 percentage point decrease in the overnight rate leads lowly capitalized banks to grant loans that are 5 percent more likely to default in the

\footnotetext{
${ }^{32}$ We also study how loan maturity is affected. The estimates are not robust in statistical significance.
} 
future than highly capitalized banks (that have 1 standard deviation more in capitalization), while the estimated coefficients on funds rate, securitization, and current account are not statistically significant.

Finally, model (6) presents estimates on future loan defaults of the benchmark regression model (4) without controlling for the sample selection bias of the first stage. We find that not correcting for the sample selection reduces the potency of the risk-taking channel of monetary policy by 49 percent, though this strong decrease is not robust to the use of alternative methods.

Table VI similarly analyzes the absence of collateral requirements with representative models from Tables II and III. Model (2), for example, is the equivalent of the loaded specification model (5) in Table III. The estimates show that a decrease in the overnight rate leads lowly capitalized banks to be more likely to grant loan applications to risky firms and that the granted loans to these firms are more likely to be uncollateralized (at its mean) by almost 7 percent, while the estimated coefficients on the funds rate, securitization, and current account are again not statistically significant. Results are stronger statistically and economically if we control for loan volume (not reported in the main tables), likely because when the overnight rate is lower, banks with lower capital grant more credit volume to riskier firms. Therefore, to be compensated for this higher risk on credit volume, banks ask for higher collateral. Model (3) in Table VI again shows that controlling for the granting of loan applications is important, since otherwise the potency of the risk-taking channel is biased downward as in the case of credit volume and future loan defaults.

In sum, we find statistically robust and economically relevant evidence that a decrease in the overnight interest rate leads lowly capitalized banks to grant more loan applications (than highly capitalized banks) to ex ante risky firms and that, when granted to risky firms, the committed loan amounts are larger and more likely to be uncollateralized, and that the overall loans that are granted are more likely to default in the future. A decrease in the long-term interest rate or changes in other relevant aggregate variables have no such effects.

\section{CONCLUSIONS}

We identify the impact of the business cycle on the composition of the supply of credit. In particular, we analyze the impact of the overnight monetary policy rate on risk-taking by banks. Spain offers an ideal setting for identification. Its economic system is dominated by banks and it had a fairly exogenous monetary policy. The Credit Register managed by the Banco de España, the banking supervisor, contains exhaustive data on all outstanding business loan contracts at a quarterly frequency since 1984:I and, crucial for our purposes, on loan applications with their loan outcomes at a monthly frequency since 2002:02. 
We find that a lower overnight interest rate induces banks to engage in higher risk-taking in their lending. Moreover, a lower overnight interest rate induces lowly capitalized banks to grant more loan applications to ex ante risky firms than highly capitalized banks and that, when granted, the committed loans are larger in volume and are more likely to be uncollateralized. Applications granted by lowly capitalized banks also have a higher ex post likelihood of default (when the overnight rate is lower). A lower long-term interest rate and other key macro variables such as securitization and current account deficits (which entail capital inflows) have no such effects. In sum, monetary policy affects the composition of the supply of credit, in particular with respect to credit risk.

As we exhaustively account for time-varying bank heterogeneity, our results suggest that when the monetary policy rate is lower, the intensity of risk-taking is not simply the result of more lending by capital-constrained banks (as in Adrian and Shin (2011)), but is also consistent with risk-shifting (as in Rajan (2006) or several models summarized in Allen and Rogoff (2011)). As we find that monetary policy drives bank risk-taking, our results lend support to the bestowing of new responsibilities to central banks in the realm of macroprudential supervision (Diamond and Rajan (2012)). Monetary and macroprudential policies may indeed not be independent (Goodhart (1988), Stein (2012)).

Schularick and Taylor (2012), Gourinchas and Obstfeld (2012), and others found that of all factors considered, credit booms have the highest ex ante correlation with banking crises. Given that these papers study either long historical time series or large cross-country data sets, they only have access to aggregate measures. However, more important than the volume of credit is probably the compositional change in the supply of credit, in particular with respect to risk. Our paper is a first step in this direction.

There are a number of natural extensions to our study. We currently focus on the impact of monetary policy on individual loan granting, but overlook the correlations between borrower risk and the impact on each individual bank's portfolio, or the correlations between all the banks' portfolios and the resulting systemic risk impact of monetary policy. In addition, we focus on the effects of one aggregate variable on one dimension of the composition of the supply of credit, that is, monetary policy and firm credit risk. As highlighted by Matsuyama (2007b), low-frequency macro variation and firm investment growth opportunities may be a natural and very interesting avenue for further exploration. We leave these and other extensions for future work. 
TABLE VII

DEFINITIONS OF All VARIABLES USED IN THE EstimATIONS

\begin{tabular}{|c|c|c|}
\hline Variable Name & Unit & Definition \\
\hline \multicolumn{3}{|l|}{ Dependent Variables } \\
\hline$I\left(\right.$ GRANTING OF LOAN APPLICATIONS $\left._{t b i}\right)$ & $0 / 1$ & $\begin{array}{l}\text { A dummy variable, which equals } 1 \text { if the loan application made in } \\
\text { month } t \text { to bank } b \text { by firm } i \text { is successful and the loan is granted in } \\
t \text { to } t+3 \text {, and equals } 0 \text { otherwise }\end{array}$ \\
\hline LN(CREDIT AMOUNT $\left.{ }_{t b i}\right)$ & $\ln (000$ Euros $)$ & $\begin{array}{l}\text { The logarithm of the committed loan amount granted in months } \\
t \text { to } t+3 \text { by bank } b \text { to firm } i \text { following a successful application filed } \\
\text { in month } t \text { to bank } b \text { by firm } i\end{array}$ \\
\hline$I\left(\right.$ FUTURE DEFAULT $\left._{t b i}\right)$ & $0 / 1$ & $\begin{array}{l}\text { A dummy variable, which equals } 1 \text { when firm } i \text { that is granted the } \\
\text { loan in month } t \text { by bank } b \text { defaults at some point in the future, and } \\
\text { equals } 0 \text { otherwise }\end{array}$ \\
\hline$I\left(\right.$ WITHOUT COLLATERAL $\left._{t b i}\right)$ & $0 / 1$ & $\begin{array}{l}\text { A dummy variable, which equals } 1 \text { if the loan granted in month } t \\
\text { by bank } b \text { by firm } i \text { is uncollateralized, and equals } 0 \text { otherwise }\end{array}$ \\
\hline \multicolumn{3}{|l|}{ Independent Variables } \\
\hline \multicolumn{3}{|l|}{ Firm-Level Credit Risk Variables } \\
\hline$I\left(\right.$ FIRM RISK $\left._{t i}\right)$ & $0 / 1$ & $\begin{array}{l}\text { A dummy variable, which equals } 1 \text { if in month } t \text { the firm had } \\
\text { nonperforming loans outstanding } 4 \text { years prior to the loan } \\
\text { application, and equals } 0 \text { otherwise }\end{array}$ \\
\hline \multicolumn{3}{|l|}{ Macro-Level Variables } \\
\hline$\Delta$ OVERNIGHT RATE $_{t-1}$ & $\%$ & $\begin{array}{l}\text { The annual change in the Euro overnight index average rate } \\
\text { (EONIA), which is the target interest rate for monetary policy in } \\
\text { the Eurosystem, and before } 1998 \text { the change in the Spanish } \\
\text { overnight interest rate at } t-1\end{array}$ \\
\hline$\Delta \mathrm{GDP}_{t-1}$ & $\%$ & $\begin{array}{l}\text { Annual change of Spanish gross domestic product in real terms } \\
\text { at } t-1\end{array}$ \\
\hline$\Delta \mathrm{CPI}_{t-1}$ & $\%$ & Annual change of Spanish Consumer Price Index at $t-1$ \\
\hline
\end{tabular}


TABLE VII-Continued

\begin{tabular}{|c|c|c|}
\hline Variable Name & Unit & Definition \\
\hline \multicolumn{3}{|l|}{ Additional Macro-Level Controls } \\
\hline$\Delta$ SPANISH LONG-TERM INTEREST RATE ${ }_{t-1}$ & $\%$ & $\begin{array}{l}\text { The annual change in the } 10 \text {-year Spanish government bond rate } \\
\text { at } t-1\end{array}$ \\
\hline$\Delta$ U.S. SHORT-TERM INTEREST RATE R-1 $_{t}$ & $\%$ & The annual change in the U.S. Federal funds rate at $t-1$ \\
\hline$\Delta$ U.S. LONG-TERM INTEREST RATE R $_{t-1}$ & $\%$ & $\begin{array}{l}\text { The annual change in the } 10 \text {-year U.S. government bond rate } \\
\text { at } t-1\end{array}$ \\
\hline$\Delta$ SPANISH SECURITIZED ASSETS/TOT. ASSETS ${ }_{t-1}$ & $\%$ & $\begin{array}{l}\text { The annual change in assets that were securitized bay Spanish } \\
\text { banks at } t-1\end{array}$ \\
\hline$\Delta$ SPANISH CURRENT ACCOUNT DEFICIT/GDP ${ }_{t-1}$ & $\%$ & $\begin{array}{l}\text { The annual change in the Spanish current account deficit over } \\
\text { GDP at } t-1\end{array}$ \\
\hline \multicolumn{3}{|l|}{ Bank-Level Variables } \\
\hline \multicolumn{3}{|l|}{ Bank Risk-Taking Variable } \\
\hline LN(BANK CAPITAL B $\left._{t-1 b}\right)$ & - & $\begin{array}{l}\text { The logarithm of the ratio of bank equity over total assets of the } \\
\text { bank at } t-1\end{array}$ \\
\hline \multicolumn{3}{|l|}{ Bank Controls } \\
\hline LN(TOTAL ASSETS AT $\left._{t-1 b}\right)$ & $\ln (000$ Euros $)$ & The logarithm of the total assets of the bank \\
\hline LIQUIDITY RATIO $_{t-1 b}$ & $\%$ & $\begin{array}{l}\text { The ratio of liquid assets (cash and balance with central banks, } \\
\text { and loans and advances to governments and credit institutions) } \\
\text { held by the bank over the total assets of the bank }\end{array}$ \\
\hline $\mathrm{ROA}_{t-1 b}$ & $\%$ & The total net income over assets of the bank \\
\hline NPL RATIO $_{t-1 b}$ & $\%$ & The nonperforming loan ratio of the bank \\
\hline$I\left(\mathrm{COMMERCIAL} \mathrm{BANK}_{b}\right)$ & $0 / 1$ & $\begin{array}{l}\text { A dummy variable, which equals } 1 \text { if the bank is a commercial } \\
\text { bank and equals } 0 \text { otherwise }\end{array}$ \\
\hline$I\left(\right.$ SAVINGS BANK $\left._{b}\right)$ & $0 / 1$ & $\begin{array}{l}\text { A dummy variable, which equals } 1 \text { if the bank } \\
\text { is a savings bank and equals } 0 \text { otherwise }\end{array}$ \\
\hline
\end{tabular}




\section{REFERENCES}

ACHARYA, V. V., AND P. SCHNABL (2009): "How Banks Played the Leverage Game," in Restoring Financial Stability: How to Repair a Failed System? ed. by V. V. Acharya and M. Richardson. New York: Wiley, 83-100. [473]

ADRIAN, T., AND H. S. SHIN (2011): "Financial Intermediaries and Monetary Economics," in Handbook of Monetary Economics, Vol. 3a, ed. by B. M. Friedman and M. Woodford. New York: Elsevier, 601-650. [464,468,493,499]

ALLEN, F., AND D. GALE (2000): "Bubbles and Crises," Economic Journal, 110, 236-255. [464] (2004): "Asset Price Bubbles and Monetary Policy," in Global Governance and Financial Crises, ed. by M. Desai and Y. Said. London: Routledge, 19-42. [464,494]

(2007): Understanding Financial Crises. New York: Oxford University Press. [464]

Allen, F., AND K. Rogoff (2011): "Asset Prices, Financial Stability and Monetary Policy," in The Riksbank's Inquiry Into the Risks in the Swedish Housing Market, ed. by P. Jansson and M. Persson. Stockholm: Sveriges Riksbank, 189-218. [464,499]

Altunbas, Y., L. GambacorTA, AND D. MarqueZ-IbaÑEZ (2010): "Does Monetary Policy Affect Bank Risk-Taking?” Working Paper, Bank for International Settlements. [467]

AmEMIYA, T. (1985): Advanced Econometrics. Cambridge, MA: Harvard University Press. [466, 472]

APel, M., AND C. A. Claussen (2012): "Monetary Policy, Interest Rates and Risk-Taking," Sveriges Riksbank Economic Review, 2, 68-83. [467]

Arellano, M., AND B. E. Honoré (2001): "Panel Data Models: Some Recent Developments," in Handbook of Econometrics, ed. by J. J. Heckman and E. E. Leamer. New York: NorthHolland, 3229-3329. [472]

BANCO DE ESPAÑa (1997): La Politica Monetaria Y La Inflation En España (Monetary Policy and Inflation in Spain). Madrid: Alianza Editorial. [474]

BEKAERT, G., M. HoERova, AND M. Lo DuCA (2010): “Risk, Uncertainty and Monetary Policy,” Report, European Central Bank. [494]

Bernanke, B. S. (2010): "Monetary Policy and the Housing Bubble," Speech at the Annual Meeting, American Economic Association. [464]

Bernanke, B. S., AND A. S. Blinder (1992): "The Federal Funds Rate and the Channels of Monetary Transmission," American Economic Review, 82, 901-921. [464,468,496]

BernanKe, B. S., AND M. GerTLER (1995): "Inside the Black Box: The Credit Channel of Monetary Policy Transmission," Journal of Economic Perspectives, 9, 27-48. [465,471]

BERNANKE, B. S., AND K. N. KUTTNER (2005): "What Explains the Stock Market's Reaction to Federal Reserve Policy?" Journal of Finance, 60, 1221-1257. [493]

BORIO, C., AND H. ZHU (2008): "Capital Regulation, Risk-Taking and Monetary Policy: A Missing Link in the Transmission Mechanism," Working Paper, Bank for International Settlements. [464]

Buch, C. M., S. EicKMeIER, AND E. PriEto (2010): "Macroeconomic Factors and Micro-Level Bank Risk," Working Paper, CESifo. [467]

(2011): "In Search for Yield? Survey-Based Evidence on Bank Risk Taking,” Discussion Paper, Deutsche Bundesbank. [467]

CAMERON, A. C., AND P. K. TRIVEDi (2005): Microeconometrics: Methods and Applications. New York: Cambridge University Press. [472]

De Nicolò, G., G. Dell'Ariccia, L. LAeven, And F. VAlencia (2010): "Monetary Policy and Bank Risk-Taking," Report, International Monetary Fund. [493]

Delgado, J., V. SAlas, AND J. SAURINA (2007): "Joint Size and Ownership Specialization in Bank Lending," Journal on Banking and Finance, 31, 3563-3583. [469]

DELIS, M. D., I. HASAN, AND N. MYLONIDIS (2011): "The Risk-Taking Channel of Monetary Policy in the USA: Evidence From Micro-Level Data,” Report, Cass Business School. [467]

Dell'Ariccia, G., L. LAeven, AND G. A. SuAReZ (2013): "Bank Leverage and Monetary Policy's Risk-Taking Channel: Evidence From the United States," Report, International Monetary Fund. [467] 
Den HaAn, W. J., S. Sumner, AND G. YAmashiro (2007): "Bank Loan Portfolios and the Monetary Transmission Mechanism," Journal of Monetary Economics, 54, 904-924. [493]

DiAMOND, D. W., AND R. G. RAJAN (2012): "Illiquid Banks, Financial Stability, and Interest Rate Policy," Journal of Political Economy, 120, 552-591. [464,499]

GAGGL, P., AND M. T. VALDERRAMA (2010): "Does a Low Interest Rate Environment Affect Risk Taking in Austria?" Monetary Policy and the Economy of the Oesterreichische Nationalbank, 4, 32-48. [467]

GeršL, A., P. JAKubík, D. KowalCZYK, S. OngenA, AND J.-L. Peydró (2012): "Monetary Conditions and Banks' Behaviour in the Czech Republic,” Working Paper, Czech National Bank. [467]

GerTLER, M., AND S. Gilchrist (1994): "Monetary Policy, Business Cycles, and the Behavior of Small Manufacturing Firms," Quarterly Journal of Economics, 109, 309-340. [464,469,493]

GERTLER, M., AND N. KIYOTAKI (2011): "Financial Intermediation and Credit Policy in Business Cycle Analysis," in Handbook of Monetary Economics, Vol. 3a, ed. by B. M. Friedman and M. Woodford. New York: Elsevier, 547-599. [468]

Giannone, D., M. LenZA, ANd L. Reichlin (2010): "Business Cycles in the Euro Area," in Europe and the Euro, ed. by A. Alesina and F. Giavazzi. Cambridge, MA: National Bureau of Economic Research, 141-167. [474]

GOODHART, C. (1988): The Evolution of Central Banks. Cambridge, MA: MIT Press. [499]

GOURINCHAS, P.-O., AND M. OBSTFELD (2012): "Stories of the Twentieth Century for the TwentyFirst," American Economic Journal: Macroeconomics, 4, 226-265. [499]

HAGEN von, J., AND J. Ho (2007): "Money Market Pressure and the Determinants of Banking Crises," Journal of Money, Credit and Banking, 39, 1037-1066. [494]

Heckman, J. J. (1974): "Effects of Child-Care Programs on Women's Work Effort," Journal of Political Economy, 82, 136-163. [472]

(1979): “Sample Selection Bias as Specification Error," Econometrica, 47, 153-161. [471]

Holmstrom, B., AND J. Tirole (1997): "Financial Intermediation, Loanable Funds, and the Real Sector," Quarterly Journal of Economics, 112, 663-691. [466,473]

Honoré, B. E., AND E. KYRIAZIDOU (2000): "Panel Data Discrete Choice Models With Lagged Dependent Variables," Econometrica, 68, 839-874. [472]

Honoré, B. E., E. Kyriazidou, AND J. L. Powell (2000): "Estimation of Tobit-Type Models With Individual Specific Effects," Econometric Reviews, 19, 341-366. [472]

IoAnnidou, V. P., S. Ongena, AND J.-L. PeYdró (2009): "Monetary Policy, Risk-Taking and Pricing: Evidence From a Quasi-Natural Experiment," Report, CentER-Tilburg University/European Central Bank. [467]

JiméneZ, G., S. Ongena, J.-L. Peydró, And J. SAurina (2012): "Credit Supply and Monetary Policy: Identifying the Bank Balance-Sheet Channel With Loan Applications," American Economic Review, 102, 2301-2326. [464,468]

(2014): "Supplement to 'Hazardous Times for Monetary Policy: What Do TwentyThree Million Bank Loans Say About the Effects of Monetary Policy on Credit Risk-Taking?" Econometrica Supplemental Material, 82, http://www.econometricsociety.org/ecta/supmat/ 10104_tables.pdf; http://www.econometricsociety.org/ecta/supmat/10104_data_and_programs. zip. $[4 \overline{7} 3]$

KASHYAP, A. K., AND J. C. STEIN (2000): "What Do a Million Observations on Banks Say About the Transmission of Monetary Policy?” American Economic Review, 90, 407-428. [464,465,468, $471,473,474,496]$

KeELEy, M. C. (1990): “Deposit Insurance Risk and Market Power in Banking,” American Economic Review, 80, 1183-1200. [465]

KHWAJA, A. I., AND A. MIAN (2008): “Tracing the Impact of Bank Liquidity Shocks: Evidence From an Emerging Market," American Economic Review, 98, 1413-1442. [468,496]

Kindleberger, C. P. (1978): Manias, Panics, and Crashes: A History of Financial Crises. New York: Basic Books. [464] 
Krugman, P. R., AND M. ObSTFELD (2006): International Economics: Theory and Policy. New York: Addison-Wesley. [474]

KuRITZKeS, A., AND T. SCHUERmAnN (2010): "What We Know, Don't Know, and Can't Know About Bank Risk: A View From the Trenches," in The Known, the Unknown and the Unknowable in Financial Risk Management, ed. by F. X. Diebold, N. A. Doherty, and R. J. Herring. Princeton: Princeton University Press, 103-144. [464]

KYRIAZIDOU, E. (1997): "Estimation of a Panel Data Sample Selection Model," Econometrica, $65,1335-1364$. [472,479,482,487,489,491]

LANG, W. W., AND L. I. NAKAMURA (1995): “Flight to Quality' in Banking and Economic Activity," Journal of Monetary Economics, 36, 145-164. [469]

LÓPEZ, M., F. TENJO, AND H. ZÁRATE (2010a): “The Risk-Taking Channel and Monetary Transmission Mechanism in Colombia," Working Paper, Banco de la Republica Colombia. [467]

(2010b): “The Risk-Taking Channel in Colombia Revisited," Working Paper, Banco de la Republica Colombia. [467]

MADDALONI, A., AND J.-L. PEYDRÓ (2011): "Bank Risk-Taking, Securitization, Supervision, and Low Interest Rates: Evidence From Euro-Area and U.S. Lending Standards," Review of Financial Studies, 24, 2121-2165. [493]

MATSUYAMA, K. (2007a): "Aggregate Implications of Credit Market Imperfections," in NBER Macroeconomics Annual, ed. by D. Acemoglu, K. S. Rogoff, and M. Woodford. Chicago: University of Chicago Press, 1-60. [464] $[468,499]$

(2007b): "Credit Traps and Credit Cycles," American Economic Review, 97, 503-516.

PALIGOROVA, T., AND J. A. C. SANTOS (2012): "Monetary Policy and Bank Risk-Taking: Evidence From the Corporate Loan Market," Report, Bank of Canada. [467]

RAJAN, R. G. (2006): "Has Finance Made the World Riskier?" European Financial Management, $12,499-533$. [465,499]

(2010): Fault Lines. Princeton, NJ: Princeton University Press. [464]

Rigobon, R., AND B. SACK (2004): “The Impact of Monetary Policy on Asset Prices,” Journal of Monetary Economics, 51, 1553-1575. [494]

SCHUlarick, M., AND A. M. TAYlor (2012): "Credit Booms Gone Bust: Monetary Policy, Leverage Cycles, and Financial Crises, 1870-2008," American Economic Review, 102, 1029-1061. [499]

SMiTh, B. D. (2002): "Monetary Policy, Banking Crises, and the Friedman Rule," American Economic Review, 92, 128-134. [465]

STEIN, J. C. (2012): "Monetary Policy as Financial-Stability Regulation," Quarterly Journal of Economics, 127, 57-95. [499]

Stiglitz, J. E., AND B. GReEnwald (2003): Towards a New Paradigm in Monetary Economics. Cambridge: Cambridge University Press. [473]

Stiglitz, J. E., AND A. Weiss (1981): "Credit Rationing in Markets With Imperfect Information," American Economic Review, 71, 393-410. [465]

TAYLOR, J. (2007): “Housing and Monetary Policy," Paper Presented at a Symposium Sponsored by the Federal Reserve Bank of Kansas City at Jackson Hole WY, Federal Reserve Bank of Kansas City. [464]

WoOLDRIDGE, J. M. (1995): "Selection Corrections for Panel Data Models Under Conditional Mean Independence Assumptions," Journal of Econometrics, 68, 115-132. [472,473,496]

(2010): Econometric Analysis of Cross Section and Panel Data. Cambridge, MA: MIT Press. [472]

Banco de España, P.O. Box 28014, Alcalá 48, Madrid, Spain; gabriel.jimenez@ bde.es,

Dept. of Banking and Finance, University of Zürich, Plattenstrasse 32, CH-8032

Zürich, Switzerland; steven.ongena@bf.uzh.ch, 
ICREA-Universitat Pompeu Fabra and Barcelona GSE, Ramón Trias Fargas 25, 08005 Barcelona, Spain and Cass Business School, 106 Bunhill Row, London EC1Y 8TZ, U.K.; jose.peydro@gmail.com, jose.peydro@upf.edu, and

Banco de España, P.O. Box 28014, Alcalá 48, Madrid, Spain; jsaurina@bde.es.

Manuscript received June, 2011; final revision received May, 2013. 